\title{
Experimental characterization of n-heptane low-temperature oxidation products including keto-hydroperoxides and highly oxygenated organic molecules (HOMs).
}

\author{
Nesrine Belhadj ${ }^{1,2}$, Roland Benoit ${ }^{1}$, Philippe Dagaut ${ }^{1,{ }^{*}}$, Maxence Lailliau ${ }^{1,2}$ \\ ${ }^{1}$ CNRS-INSIS, ICARE, 1C avenue de la Recherche Scientifique, 45071 Orléans cedex 2, France \\ ${ }^{2}$ Université d'Orléans, rue de Chartres, 45100 Orléans, France
}

*Corresponding author:

Philippe Dagaut

CNRS-ICARE, Institut de Combustion, Aérothermique, Réactivité et Environnement

1C Avenue de la Recherche Scientifique

45071 Orléans Cedex 2, France

Tel: +33(0)2 38255466

dagaut@,cnrs-orleans.fr

\begin{abstract}
The oxidation of n-heptane was performed in a jet-stirred reactor (JSR) at $10 \mathrm{~atm}$, an equivalence ratio of 0.5 , and an initial fuel concentration of $1000 \mathrm{ppm}$ at a residence time of $1 \mathrm{~s}$ in the temperature range $580-790 \mathrm{~K}$ (from coolflame, negative temperature coefficient NTC, to intermediate temperature oxidation regime), and with $5000 \mathrm{ppm}$ of fuel at $647 \mathrm{~K}$ and a residence time of $1.5 \mathrm{~s}$. Low-temperature products formed in JSR were characterized using high-resolution mass spectrometry analyses (HRMS). Atmospheric pressure chemical ionizations (APCI) was used in positive and negative modes for MS analyses. Both flow injection analyses (FIA) or ultra-high-pressure liquid chromatography-Orbitrap ${ }^{\circledR}$ coupling were used to characterize hydroperoxides $\left(\mathrm{C}_{7} \mathrm{H}_{16} \mathrm{O}_{2}\right)$, keto-hydroperoxides $\left(\mathrm{C}_{7} \mathrm{H}_{14} \mathrm{O}_{3}\right)$, cyclic ethers $\left(\mathrm{C}_{7} \mathrm{H}_{14} \mathrm{O}\right)$, carboxylic acids $\left(\mathrm{C}_{2} \mathrm{H}_{4} \mathrm{O}_{2}, \mathrm{C}_{3} \mathrm{H}_{6} \mathrm{O}_{2}, \mathrm{C}_{4} \mathrm{H}_{8} \mathrm{O}_{2}\right)$, ketones $\left(\mathrm{C}_{3-5} \mathrm{H}_{6-10} \mathrm{O}\right)$, diones $\left(\mathrm{C}_{7} \mathrm{H}_{12} \mathrm{O}_{2}\right)$, and highly oxygenated molecules $\left(\mathrm{C}_{7} \mathrm{H}_{14} \mathrm{O}_{5}, \mathrm{C}_{7} \mathrm{H}_{14} \mathrm{O}_{7}, \mathrm{C}_{7} \mathrm{H}_{14} \mathrm{O}_{9}, \mathrm{C}_{7} \mathrm{H}_{14} \mathrm{O}_{11}\right)$ resulting from the addition of up to six $\mathrm{O}_{2}$ molecules on fuel radicals. $\mathrm{H} / \mathrm{D}$ exchange with $\mathrm{D}_{2} \mathrm{O}$ was used to confirm the presence of $-\mathrm{OH}$ or $\mathrm{OOH}$ groups in the products. Several available kinetic reaction mechanisms were tested against the present measurements of keto-hydroperoxides showing significant discrepancies.
\end{abstract}

Keywords: n-heptane, jet-stirred reactor, cool flame, keto-hydroperoxides, highly oxygenated molecules 


\section{Introduction}

Normal alkanes are important components of commercial jet fuels and Diesel fuels [1-3]. Among them, nheptane, a primary reference fuel for gasoline, has been considered in hundreds of oxidation studies performed over a wide range of conditions. Besides ignition delay[4] and burning velocity[5] measurements, speciation has been carried out in different experimental set-ups, e.g., shock tubes [6, 7], flow reactors [8], jet-stirred reactors [9-12], flames [13-17], rapid compression machine [18], and piston engines [12, 19]. However, as pointed out earlier [12], under low-temperature and high-pressure conditions relevant to piston engines operating conditions, no comprehensive analysis of the pool of intermediates is available, preventing detailed understanding of reaction pathways governing ignition and pollutants formation.

Until recently, the low-temperature oxidation products of n-heptane were still not well-characterized[12]. Indeed, only few studies concern the formation of low-temperature oxidation products such as organic hydroperoxides (ROOH), keto-hydroperoxides (KHPs) [20-28], and highly oxygenated molecules (HOMs) produced via newly proposed oxidation pathways [12, 29]. Wang et al. [12]reported a long list of JSR cool flame products measured by synchrotron-vacuum UV-Photoionization-Molecular beam-TOF MS (SVUV-PI-MBMS) and APCI-Orbitrap ${ }^{\circledR}$ during the stoichiometric oxidation of $1 \% \mathrm{n}$-heptane at $\sim 1$ atm and $2 \mathrm{~s}$ residence time in a JSR: $\mathrm{C}_{7} \mathrm{H}_{14} \mathrm{O}_{\mathrm{x}}(\mathrm{x}=0-5), \mathrm{C}_{7} \mathrm{H}_{12} \mathrm{O}_{\mathrm{x}}(\mathrm{x}=0-4), \mathrm{C}_{7} \mathrm{H}_{10} \mathrm{O}_{\mathrm{x}}(\mathrm{x}=0-4), \mathrm{C}_{\mathrm{n}} \mathrm{H}_{2 \mathrm{n}}(\mathrm{n}=2-6), \mathrm{C}_{\mathrm{n}} \mathrm{H}_{2 \mathrm{n}-2}(\mathrm{n}=4-6), \mathrm{C}_{\mathrm{n}} \mathrm{H}_{2 \mathrm{n}+2} \mathrm{O}(\mathrm{n}=1-4,6)$, $\mathrm{C}_{\mathrm{n}} \mathrm{H}_{2 \mathrm{n}} \mathrm{O}(\mathrm{n}=1-6), \mathrm{C}_{\mathrm{n}} \mathrm{H}_{2 \mathrm{n}-2} \mathrm{O}(\mathrm{n}=2-6), \mathrm{C}_{\mathrm{n}} \mathrm{H}_{2 \mathrm{n}-4} \mathrm{O}(\mathrm{n}=4-6), \mathrm{C}_{\mathrm{n}} \mathrm{H}_{2 \mathrm{n}+2} \mathrm{O}_{2}(\mathrm{n}=0-4,7), \mathrm{C}_{\mathrm{n}} \mathrm{H}_{2 \mathrm{n}} \mathrm{O}_{2}(\mathrm{n}=1-6), \mathrm{C}_{\mathrm{n}} \mathrm{H}_{2 \mathrm{n}-2} \mathrm{O}_{2}(\mathrm{n}=2-6)$, $\mathrm{C}_{n} \mathrm{H}_{2 n-4} \mathrm{O}_{2}(\mathrm{n}=4-7)$, and $\mathrm{C}_{n} \mathrm{H}_{2 n} \mathrm{O}_{3}(\mathrm{n}=3-6)$. Whereas the formation of HOMs in combustion is usually overlooked, they are considered of paramount importance for the formation of secondary organic aerosols (SOA) in the troposphere [30]. Chromatographic separation of KHPs, formed by oxidation of large hydrocarbons, and detection by UV absorption or mass spectrometry has been attempted in the past [20-28], but suffered from technical limitations. Nowadays, with more powerful analytical techniques such as synchrotron-based mass spectrometry [29, 31, 32], ultra-high pressure liquid chromatography (UHPLC), and high-resolution mass spectrometry (Orbitrap ${ }^{\circledR}$ ), one can expect improving the characterization of cool flame products[33].

Therefore, as part of continuing efforts in this laboratory for getting better understanding of low-temperature oxidation mechanisms of hydrocarbons, new experiments were performed in a JSR to further characterize n-heptane low temperature oxidation products using UHPLC and Orbitrap ${ }^{\circledR}$. Among these products, hydroperoxides, ketohydroperoxides, carboxylic acids, diones, cyclic ethers, and a large set of highly oxygenated molecules resulting from multiple $\mathrm{O}_{2}$ addition on fuel's radicals were tracked using soft chemical ionization and high-resolution mass spectrometry. Because several chemical kinetic reaction mechanisms in the literature [34-36] could represent JSR data obtained for stable products under this study's conditions, we used them to simulate the global formation of KHPs and other low-temperature oxidation products under the present JSR conditions.

\section{Experimental}

\subsection{JSR experiments}

Experiments were carried out in a fused silica jet-stirred reactor setup presented previously [37] and used in earlier studies $[38,39]$. The reactor is located inside a pressure-resistant stainless-steel vessel. It is surrounded by a regulated oven (ca. $1.5 \mathrm{~kW}$ ) which maintains the temperature of the reactor at the desired working temperature. The oven is thermally insulated by ceramic wool. The temperature of the gases inside the JSR are varied stepwise. As 
in previous experiments [40] the liquid fuel, freshly distillated under vacuum (n-heptane, $>99 \%$ pure from Sigma Aldrich) was atomized by a nitrogen flow and vaporized in a heated chamber. The fuel and oxygen were sent separately to the JSR to avoid oxidation before reaching the 4 injectors (nozzles of $1 \mathrm{~mm}$ I.D.) which are providing stirring. Flow rates of nitrogen and oxygen were controlled by mass flow meters. The liquid fuel was pumped by an HPLC pump (Shimadzu LC10 AD VP) equipped with an online degasser (Shimadzu DGU-20 A3). The present experimental conditions are summarized in Table 1.

Table 1. Experimental conditions

\begin{tabular}{|c|c|}
\hline \multicolumn{2}{|c|}{ Equivalence ratio $(\varphi): 0.5$} \\
Pressure: $10 \mathrm{~atm}$ \\
\hline $1000 \mathrm{ppm}$ of fuel & $5000 \mathrm{ppm}$ of fuel \\
$2 \% \mathrm{O}_{2}, 97.9 \% \mathrm{~N}_{2}$ & $10 \% \mathrm{O}_{2}, 89.5 \% \mathrm{~N}_{2}$ \\
\hline Residence time: $1 \mathrm{~s}$ & Residence time: $1.5 \mathrm{~s}$ \\
\hline T: 580 to $790 \mathrm{~K}$ & $\mathrm{~T}=647 \mathrm{~K}$ \\
\hline
\end{tabular}

Thermal homogeneity along the vertical axis of the JSR was verified by thermocouple measurements $(0.1 \mathrm{~mm}$ $\mathrm{Pt}-\mathrm{Pt} / \mathrm{Rh}-10 \%$ wires located inside a thin-wall fused-silica tube) and found good (gradients of $<1 \mathrm{~K} / \mathrm{cm}$ ). A lowpressure fused-silica sonic probe was used to stop the reactions and collect samples for off line analyses. To measure low-temperature products, e.g., cyclic ethers, hydroperoxides, keto-hydroperoxides (KHPs), di-ketohydroperoxides, keto-di-hydroperoxides, and other highly oxygenated products, the gas samples were sent to an amber glass vial containing cooled acetonitrile $\left(0^{\circ} \mathrm{C}, 25 \mathrm{~mL}\right)$ and bubbled for $75 \mathrm{~min}$. The obtained solution was stored in a freezer at $-15^{\circ} \mathrm{C}$ for further chemical analyses.

\subsection{Chemical analyses of low-temperature products}

The procedure used here is close to that employed in recent studies[41, 42]. High-resolution mass spectrometry (MS) analyses were performed by flow injection (FIA). The following conditions were used: flow of 5-8 $\mu \mathrm{L} / \mathrm{min}$ recorded for $1 \mathrm{~min}$ for data averaging. The samples were injected in the ionization chamber of an Orbitrap ${ }^{\circledR} \mathrm{Q}-$ Exactive mass spectrometer (MS) having mass resolution of $\mathrm{m} / \Delta \mathrm{m}=140,000 \mathrm{at} \mathrm{m} / \mathrm{z} 200$ and mass accuracy $<1 \mathrm{ppm}$ RMS which allows 'exact mass' measurements, not attainable with other techniques such as time-of-flight MS (mass resolution ca. 4000). Ultra-high-pressure liquid chromatography-MS (Thermo Scientific Vanquish Flex UHPLC) was also used. UHPLC presents several advantages compared to HPLC, such as shortening of analysis time while keeping high resolution, and savings in solvent volumes. For the soft ionization of products, Ion Max ${ }^{\circledR}$ atmospheric chemical ionization (APCI) was used in positive and negative modes. This technique is well suited for the detection of chemicals with moderate polarity, such as products of $n$-heptane cool flame. APCI produces very few fragment ions which facilitates products identification. Mass calibrations were performed using commercial ESI positive and negative calibration mixtures (Thermo Scientific) in flow injection mode (FIA). Ionization settings 
in FIA were: sheath gas flow of 15 a.u., auxiliary gas flow of 0 a.u., sweep gas flow of 0 a.u., capillary temperature of $255^{\circ} \mathrm{C}$, vaporizer temperature of $80^{\circ} \mathrm{C}$, corona discharge current of $1.2 \mu \mathrm{A}$, spray voltage of $2.5 \mathrm{kV}$.

UHPLC-MS analyses were performed in reverse-phase mode with a $\mathrm{C}_{18}$ analytical column (Phenomenex Luna, $\left.1.6 \mu \mathrm{m}, 100 \AA, 100 \times 2.1 \mathrm{~mm}, 40{ }^{\circ} \mathrm{C}\right) .3 \mu \mathrm{L}$ of sample were injected and eluted using appropriate water-acetonitrile (ACN) gradient at a flow rate of $250 \mu \mathrm{L} / \mathrm{min}$. APCI settings were: sheath gas flow of 50 a.u., auxiliary gas flow of 10 a.u., sweep gas flow of 0 a.u., capillary temperature of $320^{\circ} \mathrm{C}$, vaporizer temperature of $150^{\circ} \mathrm{C}$, corona discharge current of $2 \mu \mathrm{A}$, spray voltage of $4 \mathrm{kV}$. In addition to mass calibrations, the retention times and mass spectra of pure products were used to identify products by UHPLC-MS/MS (carboxylic acids, ketones, aldehydes, and diones). All the UHPLC analyses were performed using the same elution gradient water/acetonitrile (Supplementary Material 1, Table S1).

To elucidate the structure of cool flame products, MS-MS analyses were carried out at collision cell energy of $10 \mathrm{eV}$. The resulting fragments were used to determine the structure of products (Section 4). The fast OH/OD exchange $[29,41,42]$ was used to confirm the presence of $-\mathrm{OH}$ and $-\mathrm{OOH}$ groups in the products. Then, we introduced $60 \mu \mathrm{L}$ of $\mathrm{D}_{2} \mathrm{O}(99.98 \% \mathrm{D}$, Sigma-Aldrich) into $200 \mathrm{uL}$ of sample and let reaction proceed for $25 \mathrm{~min}$ (sample n-Heptane 5000 ppm, $647 \mathrm{~K}$ and $10 \mathrm{~atm}, 80 \%$ evaporated). The resulting solution was analyzed by mass spectrometry in FIA and APCI (+/-) modes.

\section{Chemical kinetic modeling}

Chemical kinetic computations were carried out with the PSR computer code [43] from the Chemkin II package[44]. Previously proposed kinetic reaction mechanisms [34-36] validated over a wide range of conditions, including those of the present study, were used. They involve both low- high -temperature chemistry, but are limited to 2 nd addition of $\mathrm{O}_{2}$ to fuel's radicals yielding keto-hydroperoxides. According to the modeling, under the present conditions, $\mathrm{n}$-heptane is mainly consumed through $\mathrm{H}$-atom abstraction by hydroxyl radicals.

Table 2. Chemical structure of fuel radicals and KHPs formed by oxidation of n-heptane.

Initial radicals formed by $\mathrm{H}$-atom abstraction on n-heptane




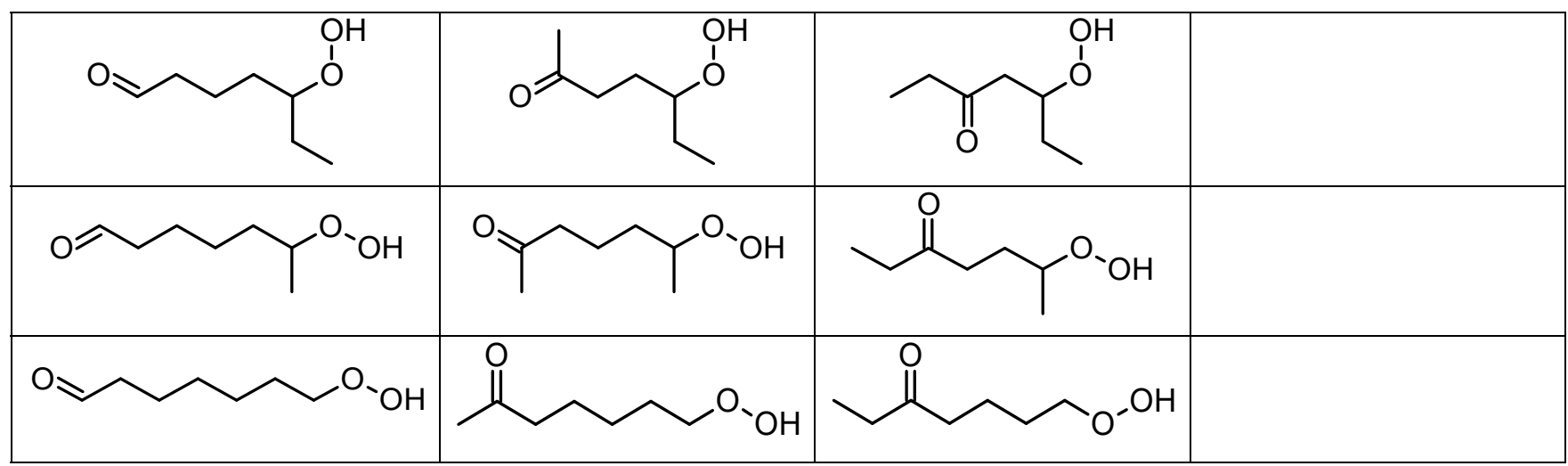

Below ca. $900 \mathrm{~K}$, the resulting 4 alkyl radicals undergo peroxidation by reaction with molecular oxygen. Four alkyl hydroperoxides can be formed after $\mathrm{H}$-atom abstraction. After internal $\mathrm{H}$-atom transfer in alkylperoxy radicals forming an alkyl hydroperoxyl radical, a second $\mathrm{O}_{2}$ addition followed by internal $\mathrm{H}$-atom transfer and decomposition, up to 21 keto-hydroperoxides can be formed (Table 2). The literature models considered here do not include further $\mathrm{O}_{2}$ additions which could yield highly oxygenated products. One should note these reaction mechanisms present differences in terms of reaction classes included, in terms of rate constants used, in terms of thermochemistry, and degree of lumping.

\section{Results and discussion}

The oxidation of $\mathrm{n}$-heptane performed in a JSR at $10 \mathrm{~atm}$ (equivalence ratio of 0.5 , initial fuel concentrations of $1000 \mathrm{ppm}(580-790 \mathrm{~K}$, residence time of $1 \mathrm{~s})$ and $5000 \mathrm{ppm}(647 \mathrm{~K}$, residence time of $1.5 \mathrm{~s})$ yielded a large variety of oxygenated low-temperature oxidation products. Their molecular formulae were $\mathrm{C}_{7} \mathrm{H}_{14} \mathrm{O}_{\mathrm{x}}(\mathrm{x}=1-12), \mathrm{C}_{7} \mathrm{H}_{12} \mathrm{O}_{\mathrm{x}}$ $(\mathrm{x}=1-12), \mathrm{C}_{7} \mathrm{H}_{10} \mathrm{O}_{\mathrm{x}}(\mathrm{x}=1-10), \mathrm{C}_{7} \mathrm{H}_{8} \mathrm{O}_{\mathrm{x}}(\mathrm{x}=2-8), \mathrm{C}_{7} \mathrm{H}_{6} \mathrm{O}_{\mathrm{x}}(\mathrm{x}=2-7), \mathrm{C}_{7} \mathrm{H}_{4} \mathrm{O}_{\mathrm{x}}(\mathrm{x}=4-6), \mathrm{C}_{\mathrm{n}} \mathrm{H}_{2 \mathrm{n}}(\mathrm{n}=4-7), \mathrm{C}_{\mathrm{n}} \mathrm{H}_{2 \mathrm{n}-2}(\mathrm{n}=4-7)$, $\mathrm{C}_{\mathrm{n}} \mathrm{H}_{2 \mathrm{n}} \mathrm{O}(\mathrm{n}=3-7), \mathrm{C}_{\mathrm{n}} \mathrm{H}_{2 \mathrm{n}-2} \mathrm{O}(\mathrm{n}=3-7), \mathrm{C}_{\mathrm{n}} \mathrm{H}_{2 \mathrm{n}-4} \mathrm{O}(\mathrm{n}=3-7), \mathrm{C}_{\mathrm{n}} \mathrm{H}_{2 \mathrm{n}+2} \mathrm{O}_{2}(\mathrm{n}=3-4,7), \mathrm{C}_{\mathrm{n}} \mathrm{H}_{2 \mathrm{n}} \mathrm{O}_{2}(\mathrm{n}=2-7), \mathrm{C}_{\mathrm{n}} \mathrm{H}_{2 \mathrm{n}-2} \mathrm{O}_{2}(\mathrm{n}=3-7)$, $\mathrm{C}_{\mathrm{n}} \mathrm{H}_{2 \mathrm{n}-4} \mathrm{O}_{2}(\mathrm{n}=3-7)$, and $\mathrm{C}_{\mathrm{n}} \mathrm{H}_{2 \mathrm{n}} \mathrm{O}_{3}(\mathrm{n}=1-7)$. Alkenes, dienes, carbonyl compounds (Supplementary Material 1, Fig. S1), organic hydroperoxides, alcohols, keto-hydroperoxides, diones, cyclic ethers, carboxylic acids, and polyoxygenated organics were observed. Indeed, besides the formation of keto-hydroperoxides, highly oxygenated compounds resulting from multiple $\mathrm{O}_{2}$ addition on the fuel's radicals (R) could be observed in this work. Their formation occurs via a sequence of reactions:

$$
\begin{gathered}
\mathrm{R}+\mathrm{O}_{2} \leftrightarrows \mathrm{RO}_{2} \\
\mathrm{RO}_{2} \leftrightarrows \mathrm{QOOH} \\
\mathrm{QOOH}+\mathrm{O}_{2} \leftrightarrows \mathrm{OOQOOH} \\
\mathrm{OOQOOH} \leftrightarrows \mathrm{HOOQ}^{\prime} \mathrm{OOH} .
\end{gathered}
$$

This last step is followed by the formation of the hydroxyl radical and a keto-hydroperoxide $\left(\mathrm{C}_{7} \mathrm{H}_{14} \mathrm{O}_{3}\right)$ :

$$
\mathrm{HOOQ}{ }^{\prime} \mathrm{OOH} \rightarrow \text { HOOQ'O }+\mathrm{OH} .
$$

Alkyl-di-hydroperoxyl radicals can also react with molecular oxygen ( $3^{\text {rd }} \mathrm{O}_{2}$ addition), followed by isomerization and decomposition of alkyl hydroperoxyl radicals: 


$$
\begin{gathered}
\mathrm{HOOQ} \mathrm{OOH}^{+} \mathrm{O}_{2} \leftrightarrows(\mathrm{HOO})_{2} \mathrm{Q}^{\prime} \mathrm{OO} \\
(\mathrm{HOO})_{2} \mathrm{Q}^{\prime} \mathrm{OO} \leftrightarrows(\mathrm{HOO})_{2} \mathrm{POOH} \\
(\mathrm{HOO})_{2} \mathrm{POOH} \rightarrow \mathrm{OH}+(\mathrm{HOO})_{2} \mathrm{P}=\mathrm{O}\left(\mathrm{C}_{7} \mathrm{H}_{14} \mathrm{O}_{5}\right)
\end{gathered}
$$

A $4^{\text {th }} \mathrm{O}_{2}$ addition can also occur and follow the same pathway:

$$
\begin{gathered}
(\mathrm{HOO})_{2} \mathrm{POOH}+\mathrm{O}_{2} \rightarrow(\mathrm{HOO})_{3} \mathrm{POO} \\
(\mathrm{HOO})_{3} \mathrm{POO} \leftrightarrows(\mathrm{HOO})_{3} \mathrm{P}^{\prime} \mathrm{OOH} \\
(\mathrm{HOO})_{3} \mathrm{P}^{\prime} \mathrm{OOH} \rightarrow \mathrm{OH}+(\mathrm{HOO})_{3} \mathrm{P}^{\prime}=\mathrm{O}\left(\mathrm{C}_{7} \mathrm{H}_{14} \mathrm{O}_{7}\right) .
\end{gathered}
$$

If the reactions proceed further with 5 th and 6th $\mathrm{O}_{2}$ addition, they could yield $\mathrm{C}_{7} \mathrm{H}_{14} \mathrm{O}_{9}$ and $\mathrm{C}_{7} \mathrm{H}_{14} \mathrm{O}_{11}$, respectively. Indeed, the products of second to 6th dioxygen addition were observed in the present experiments, as described latter in this section. Our results confirm the extended oxidation pathways proposed earlier [12, 29], based on JSR experiments performed with synchrotron vacuum ultraviolet photoionization molecular beam-time of flight mass spectrometry (SVUV-MB-TOF-MS) [12,29], which allowed the detection of products of the second and third $\mathrm{O}_{2}$ addition $\left(\mathrm{C}_{7} \mathrm{H}_{14} \mathrm{O}_{3}\right.$ and $\mathrm{C}_{7} \mathrm{H}_{14} \mathrm{O}_{5}$, respectively).

Once peroxy radicals $\left(\mathrm{RO}_{2}\right)$ are formed, they start to generate other oxygenated species. Among them, one founds hydroperoxides which are most likely produced by $\mathrm{H}$-atom abstraction by $\mathrm{RO}_{2}: \mathrm{RO}_{2}+\mathrm{R}^{\prime} \mathrm{H} \rightarrow \mathrm{ROOH}+\mathrm{R}$ ', $\mathrm{RO}_{2}+\mathrm{HO}_{2} \rightarrow \mathrm{ROOH}+\mathrm{O}_{2}$. The formation of hydroperoxides, $\mathrm{ROOH}$, was observed in the present experiments (Table 3). However, diols with the same global formula, which could derive from di-hydroperoxides decomposition [25], could not be observed here, as shown by absence of double H/D exchange (Table 2). Figure 1 presents the variation of the integrated ROOH signal obtained by UHPLC as a function of temperature. Simulations using the model of Glaude et al.[36] indicate a maximum difference of $\sim 30 \mathrm{~K}$ between data and prediction of peak concentration of $\mathrm{ROOH}$. This is consistent with deviations observed for other products as presented below.

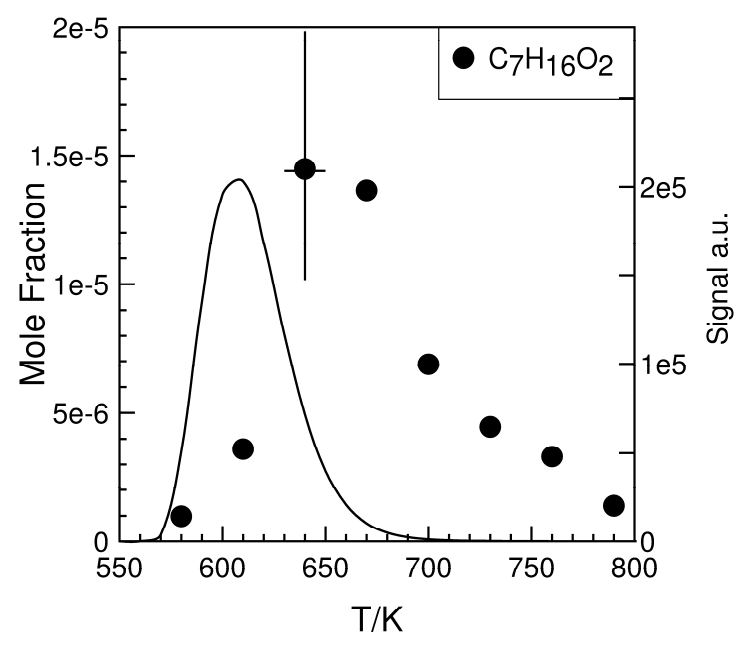

Fig. 1. Formation of $\mathrm{ROOH}\left(\mathrm{C}_{7} \mathrm{H}_{16} \mathrm{O}_{2}\right)$ in a JSR where $1000 \mathrm{ppm}$ of fuel are oxidized. Analyses were performed in APCI $(+)$ mode. Comparison of data (symbols) and modeling results (line) using the model of Glaude et al.[36]. For convenience, the raw data are scaled to modeling results[36]. The raw signal intensity is given on the right $\mathrm{Y}$-axis. Experimental errors are estimated to be of the order of $40 \%$, as in previous works [41, 42]. 
Table 3. Products of n-heptane (5000 ppm) oxidation in a JSR at $647 \mathrm{~K}$ and $10 \mathrm{~atm}$. H/D exchange by addition of $\mathrm{D}_{2} \mathrm{O} 60 \mu \mathrm{L}$ of $\mathrm{D}_{2} \mathrm{O}$ to $200 \mu \mathrm{L}$ of sample (evaporated $80 \%$ ) (reaction time: $25 \mathrm{~min}$ ). Analyses performed in FIA APCI (+/-) modes. Newly observed products are indicated by an asterisk.

\begin{tabular}{|c|c|c|c|c|c|c|}
\hline \multirow{2}{*}{$\begin{array}{l}\mathrm{M} \\
(\mathrm{g} / \mathrm{mole})\end{array}$} & \multicolumn{2}{|r|}{ Species } & \multicolumn{2}{|c|}{ APCI $(+)$} & \multicolumn{2}{|c|}{ APCI $(-)$} \\
\hline & Formula & Name & $\mathrm{m} / \mathrm{z}(\mathrm{H}+)$ & $\begin{array}{l}\text { Signal } \\
\text { (a.u) }\end{array}$ & $\mathrm{m} / \mathrm{z}(\mathrm{H}-)$ & $\begin{array}{l}\text { Signal } \\
\text { (a.u) }\end{array}$ \\
\hline 30 & $\mathrm{CH}_{2} \mathrm{O}$ & Formaldehyde & - & - & $\begin{array}{l}75.0088 \\
\text { HCOO- } \\
\text { Adduct }\end{array}$ & $5.18 \mathrm{E} 8$ \\
\hline 44 & $\mathrm{C}_{2} \mathrm{H}_{4} \mathrm{O}$ & Acetaldehyde & - & - & $\begin{array}{l}89.0246 \\
\text { HCOO- } \\
\text { Adduct }\end{array}$ & $1.43 \mathrm{E} 8$ \\
\hline 46 & $\mathrm{CH}_{2} \mathrm{O}_{2}$ & Methanoic acid & - & - & $\begin{array}{l}91.0038 \\
\text { HCOO- } \\
\text { Adduct }\end{array}$ & $6.61 \mathrm{E} 6$ \\
\hline 47 & $\mathrm{CH}_{1} \mathrm{DO}_{2}$ & Methanoic acid-d1 & - & - & $\begin{array}{l}92.0101 \\
\text { HCOO- } \\
\text { Adduct }\end{array}$ & $4.96 \mathrm{E} 6$ \\
\hline 58 & $\mathrm{C}_{3} \mathrm{H}_{6} \mathrm{O}$ & Acetone & 59.0492 & $8.84 \mathrm{E} 5$ & 57.0346 & $4.30 \mathrm{E} 6$ \\
\hline 60 & $\mathrm{C}_{2} \mathrm{H}_{4} \mathrm{O}_{2}$ & Acetic acid & 61.0284 & $2.48 \mathrm{E} 6$ & 59.0139 & $2.34 \mathrm{E} 7$ \\
\hline 61 & $\mathrm{C}_{2} \mathrm{H}_{3} \mathrm{DO}_{2}$ & Acetic acid-d1 & 62.0347 & $1.63 E 6$ & 60.0202 & $4.78 E 6$ \\
\hline 72 & $\mathrm{C}_{4} \mathrm{H}_{8} \mathrm{O}$ & Butan-2-one & 73.0647 & $1.12 \mathrm{E} 6$ & 71.0503 & $4.57 \mathrm{E} 6$ \\
\hline 74 & $\mathrm{C}_{3} \mathrm{H}_{6} \mathrm{O}_{2}$ & Propanoic acid & 75.0440 & $3.02 \mathrm{E} 6$ & 73.0296 & $3.02 \mathrm{E} 7$ \\
\hline $75^{*}$ & $\mathrm{C}_{3} \mathrm{H}_{5} \mathrm{DO}_{2}$ & Propanoic acid-dl & 76.0503 & $1.81 E 6$ & 74.0359 & $1.11 E 7$ \\
\hline 86 & $\mathrm{C}_{5} \mathrm{H}_{10} \mathrm{O}$ & Pentan-2-one & 87.0804 & $3.21 \mathrm{E} 5$ & 85.0660 & $9.70 \mathrm{E} 5$ \\
\hline 88 & $\mathrm{C}_{4} \mathrm{H}_{8} \mathrm{O}_{2}$ & Butanoic acid & 89.0596 & $1.20 \mathrm{E} 6$ & 87.0453 & $1.00 \mathrm{E} 7$ \\
\hline $89^{*}$ & $\mathrm{C}_{4} \mathrm{H}_{7} \mathrm{DO}_{2}$ & Butanoic acid-d1 & 90.0659 & $1.95 E 5$ & 88.0516 & $4.02 E 6$ \\
\hline 98 & $\mathrm{C}_{7} \mathrm{H}_{14}$ & Heptene & 99.1168 & $1.61 \mathrm{E} 4$ & - & - \\
\hline 100 & $\mathrm{C}_{6} \mathrm{H}_{12} \mathrm{O}$ & Hexan-2-one & 101.0961 & $4.74 \mathrm{E} 4$ & 99.0817 & $1.68 \mathrm{E} 5$ \\
\hline 102 & $\mathrm{C}_{5} \mathrm{H}_{10} \mathrm{O}_{2}$ & Pentanoic acid & 103.0753 & $2.02 \mathrm{E} 6$ & 101.0609 & $2.3 \mathrm{E} 6$ \\
\hline $103 *$ & $\mathrm{C}_{5} \mathrm{H}_{9} \mathrm{DO}_{2}$ & Pentanoic acid-d 1 & 104.0815 & $1.30 E 6$ & 102.0672 & $7.07 E 5$ \\
\hline 112 & $\mathrm{C}_{7} \mathrm{H}_{12} \mathrm{O}$ & Heptenal & 113.0960 & $6.20 \mathrm{E} 9$ & 111.0817 & $5.63 \mathrm{E} 5$ \\
\hline 114 & $\mathrm{C}_{7} \mathrm{H}_{14} \mathrm{O}$ & $\begin{array}{l}\text { Heptanal, Heptanone and } \\
\text { cyclic ethers }\end{array}$ & 115.1116 & $2.94 \mathrm{E} 6$ & 113.0975 & 7.34E4 \\
\hline 116 & $\mathrm{C}_{7} \mathrm{H}_{16} \mathrm{O}$ & Heptanol & 117.1273 & - & 115.1130 & $2.33 \mathrm{E} 4$ \\
\hline 117 & $\mathrm{C}_{7} \mathrm{H}_{15} \mathrm{DO}$ & Heptanol-d1 & - & - & - & (a) \\
\hline 116 & $\mathrm{C}_{6} \mathrm{H}_{12} \mathrm{O}_{2}$ & Hexanoic acid & 117.0909 & $5.46 E 6$ & 115.0766 & $1.44 E 6$ \\
\hline $117 *$ & $\mathrm{C}_{6} \mathrm{H}_{11} \mathrm{DO}_{2}$ & Hexanoic acid-dl & 118.0971 & $4.74 E 6$ & 116.0829 & $3.47 E 5$ \\
\hline 128 & $\mathrm{C}_{7} \mathrm{H}_{12} \mathrm{O}_{2}$ & di-ketones & 129.0907 & $3.83 \mathrm{E} 8$ & 127.0766 & $3.83 \mathrm{E} 7$ \\
\hline 130 & $\mathrm{C}_{7} \mathrm{H}_{14} \mathrm{O}_{2}$ & Heptanoic acid & 131.1065 & $1.70 \mathrm{E} 8$ & 129.0923 & $2.88 \mathrm{E} 6$ \\
\hline $131 *$ & $\mathrm{C}_{7} \mathrm{H}_{13} \mathrm{DO} \mathrm{O}_{2}$ & Heptanoic acid-d1 & 131.1128 & $1.67 E 8$ & 130.0985 & $8.81 E 4$ \\
\hline 132 & $\mathrm{C}_{7} \mathrm{H}_{16} \mathrm{O}_{2}$ & ROOH (heptyl hydroperoxyde) & 133.1221 & $4.98 \mathrm{E} 4$ & 131.1078 & $1.25 \mathrm{E} 4$ \\
\hline $133 *$ & $\mathrm{C}_{7} \mathrm{H}_{15} \mathrm{DO}_{2}$ & heptyl hydroperoxide-dl & 134.1284 & $9.62 E 4$ & - & - \\
\hline 134 & $\mathrm{C}_{7} \mathrm{H}_{14} \mathrm{D}_{2} \mathrm{O}_{2}$ & (b) & - & - & - & - \\
\hline 144 & $\mathrm{C}_{7} \mathrm{H}_{12} \mathrm{O}_{3}$ & Unsaturated KHPs & 145.0858 & $1.58 \mathrm{E} 7$ & 143.0715 & $5.56 \mathrm{E} 6$ \\
\hline $145^{*}$ & $\mathrm{C}_{7} \mathrm{H}_{11} \mathrm{DO}_{3}$ & Unsaturated KHPs-d1 & 146.0921 & $8.40 E 6$ & 144.0779 & $2.89 E 6$ \\
\hline 146 & $\mathrm{C}_{7} \mathrm{H}_{14} \mathrm{O}_{3}$ & KHP and isomers & 147.1014 & $4.70 \mathrm{E} 6$ & 145.0872 & $2.04 \mathrm{E} 6$ \\
\hline $147^{*}$ & $\mathrm{C}_{7} \mathrm{H}_{13} \mathrm{DO} \mathrm{O}_{3}$ & KHP and isomers-dl & 148.1077 & $3.19 E 6$ & 146.0935 & $1.49 E 6$ \\
\hline $148^{*}$ & $\mathrm{C}_{7} \mathrm{H}_{12} \mathrm{D}_{2} \mathrm{O}_{3}$ & Isomers- $d 2$ & 149.1140 & $1.71 E 5$ & 147.0996 & $4.03 E 3$ \\
\hline 160 & $\mathrm{C}_{7} \mathrm{H}_{12} \mathrm{O}_{4}$ & Diketo-ROOH & 161.0807 & $1.80 \mathrm{E} 6$ & 159.0665 & $1.7 \mathrm{E} 7$ \\
\hline $161 *$ & $\mathrm{C}_{7} \mathrm{H}_{11} \mathrm{DO}_{4}$ & Diketo-ROOH-d1 & 162.0869 & $1.34 E 6$ & 160.0728 & $1.16 E 7$ \\
\hline 162 & $\mathrm{C}_{7} \mathrm{H}_{14} \mathrm{O}_{4}$ & olefinic dihydroperoxide & 163.0965 & $2.19 \mathrm{E} 4$ & 161.0821 & $3.65 \mathrm{E} 6$ \\
\hline $163^{*}$ & $\mathrm{C}_{7} \mathrm{H}_{13} \mathrm{DO}_{4}$ & olefinic dihydroperoxide-d1 & 164.1027 & - & 162.0885 & $7.45 E 6$ \\
\hline $164^{*}$ & $\mathrm{C}_{7} \mathrm{H}_{12} \mathrm{D}_{2} \mathrm{O}_{4}$ & olefinic dihydroperoxide- $d 2$ & - & - & 163.0947 & $3.41 E 6$ \\
\hline 165 & $\mathrm{C}_{7} \mathrm{H}_{11} \mathrm{D}_{3} \mathrm{O}_{4}$ & (c) & - & - & - & - \\
\hline $176^{*}$ & $\mathrm{C}_{7} \mathrm{H}_{12} \mathrm{O}_{5}$ & Unsaturated KHPs & 177.0754 & $1.07 \mathrm{E} 4$ & 175.0614 & $3.63 \mathrm{E} 7$ \\
\hline $177^{*}$ & $\mathrm{C}_{7} \mathrm{H}_{11} \mathrm{DO} \mathrm{O}_{5}$ & Unsaturated KHPs-d1 & 178.0820 & $9.49 E 3$ & 176.0677 & $3.59 E 7$ \\
\hline $178^{*}$ & $\mathrm{C}_{7} \mathrm{H}_{10} \mathrm{D}_{2} \mathrm{O}_{5}$ & Unsaturated KHPs-d2 & 179.0883 & - & 177.0739 & $2.50 E 6$ \\
\hline
\end{tabular}




\begin{tabular}{|c|c|c|c|c|c|c|}
\hline 178 & $\mathrm{C}_{7} \mathrm{H}_{14} \mathrm{O}_{5}$ & Keto-di-ROOH & 179.0914 & - & 177.0771 & $5.75 \mathrm{E} 5$ \\
\hline $179 *$ & $C_{7} H_{13} D_{5}$ & Keto-di-ROOH-dl & - & - & 178.0834 & $1.14 E 6$ \\
\hline $180^{*}$ & $\mathrm{C}_{7} \mathrm{H}_{12} \mathrm{D}_{2} \mathrm{O}_{5}$ & Keto-di-ROOH-d2 & - & - & 179.0897 & $5.45 E 5$ \\
\hline $192 *$ & $\mathrm{C}_{7} \mathrm{H}_{12} \mathrm{O}_{6}$ & di-keto-di-ROOH & 193.0707 & $1.57 \mathrm{E} 4$ & 191.0563 & $3.80 \mathrm{E} 6$ \\
\hline $193 *$ & $C_{7} H_{11} D O_{6}$ & di-keto-di-ROOH-d1 & 195.0769 & - & 192.0627 & $3.95 E 6$ \\
\hline $194^{*}$ & $\mathrm{C}_{7} \mathrm{H}_{10} \mathrm{D}_{2} \mathrm{O}_{6}$ & di-keto-di-ROOH-d2 & - & - & 193.0689 & $4.23 E 6$ \\
\hline 208 & $\mathrm{C}_{7} \mathrm{H}_{12} \mathrm{O}_{7}$ & tri-keto-di-ROOH & 209.0657 & $5.44 \mathrm{E} 3$ & 207.0713 & $2.40 \mathrm{E} 6$ \\
\hline 209 & $\mathrm{C}_{7} \mathrm{H}_{11} \mathrm{D} 1 \mathrm{O}_{7}$ & tri-keto-di-ROOH-d1 & - & - & 208.0576 & $5.64 \mathrm{e} 6$ \\
\hline 210 & $\mathrm{C}_{7} \mathrm{H}_{10} \mathrm{D} 2 \mathrm{O}_{7}$ & tri-keto-di-ROOH-d2 & - & - & 209.0639 & $3.57 \mathrm{e} 6$ \\
\hline $210 *$ & $\mathrm{C}_{7} \mathrm{H}_{14} \mathrm{O}_{7}$ & di-Keto-tri-ROOH & 211.0812 & - & 209.0669 & $7.96 \mathrm{E} 5$ \\
\hline $211^{*}$ & $\mathrm{C}_{7} \mathrm{H}_{13} \mathrm{DO}_{7}$ & di-Keto-tri-ROOH-d1 & - & - & 210.0733 & $2.94 E 6$ \\
\hline $212^{*}$ & $\mathrm{C}_{7} \mathrm{H}_{12} \mathrm{D}_{2} \mathrm{O}_{7}$ & di-Keto-tri-ROOH-d2 & - & - & 211.0796 & $2.97 E 6$ \\
\hline $213 *$ & $\mathrm{C}_{7} \mathrm{H}_{11} \mathrm{D}_{3} \mathrm{O}_{7}$ & di-keto-tri-ROOH-d3 & - & - & 212.0859 & $1.13 E 6$ \\
\hline $242 *$ & $\mathrm{C}_{7} \mathrm{H}_{14} \mathrm{O}_{9}$ & HOMs: keto quadri-ROOH & 243.0710 & - & 241.0570 & $9.13 \mathrm{E} 4$ \\
\hline $243 *$ & $C_{7} H_{13} D O_{9}$ & $H O M s-d 1$ & - & - & 242.0632 & $1.22 E 6$ \\
\hline $244^{*}$ & $\mathrm{C}_{7} \mathrm{H}_{12} \mathrm{D}_{2} \mathrm{O}_{9}$ & $H O M s-d 2$ & - & - & 243.0693 & $1.39 E 6$ \\
\hline $245^{*}$ & $\mathrm{C}_{7} \mathrm{H}_{11} \mathrm{D}_{3} \mathrm{O}_{9}$ & $H O M s-d 3$ & - & - & 244.0757 & $5.21 E 5$ \\
\hline $246^{*}$ & $\mathrm{C}_{7} \mathrm{H}_{10} \mathrm{D}_{4} \mathrm{O}_{9}$ & $H O M s-d 4$ & - & - & 245.0852 & $1.11 E 4$ \\
\hline $274 *$ & $\mathrm{C}_{7} \mathrm{H}_{14} \mathrm{O}_{11}$ & HOMs & - & - & 273.0472 & $1.05 \mathrm{E} 4$ \\
\hline $275^{*}$ & $C_{7} H_{13} D O_{11}$ & $H O M s-d 1$ & - & - & 274.0534 & $3.30 E 3$ \\
\hline
\end{tabular}

Note: \# identification verified by UHPLC-MS-MS of the pure compound in ACN; * not reported previously; (a)

Below detection limit; (b) Not detected; tends to indicate diols are not detectable if formed; (c) Not detected indicating only $2-\mathrm{OOH}$ groups are present.

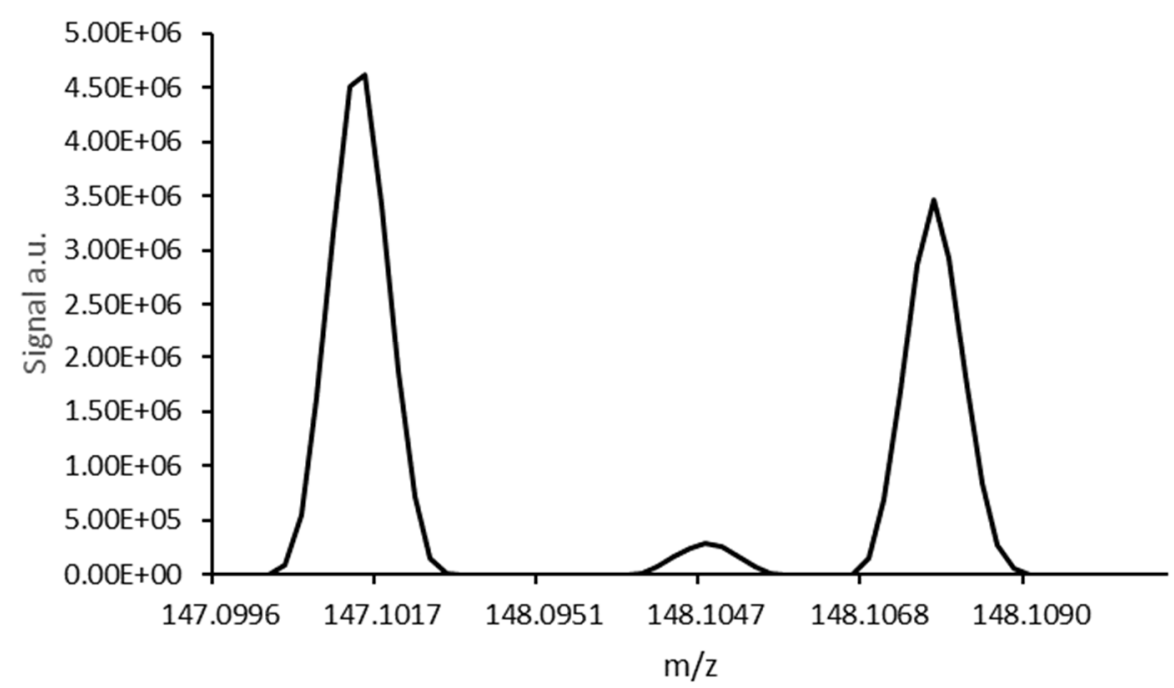

Fig. 2. Mass spectrum showing the formation of $\mathrm{C}_{7} \mathrm{H}_{14} \mathrm{DO}_{3}{ }^{+}$due to $\mathrm{OH} / \mathrm{OD}$ exchange on KHPs. $\mathrm{C}_{7} \mathrm{H}_{14} \mathrm{DO}_{3}{ }^{+}$could not be observed without addition of $\mathrm{D}_{2} \mathrm{O}$. Analyses were performed in FIA APCI $(+)$ using the concentrated $(80 \%$ evaporated) sample obtained by oxidation of $\mathrm{n}$-heptane at $640 \mathrm{~K}$. The signal at $\mathrm{m} / \mathrm{z} 148.1047$ corresponds to $\mathrm{C}_{6}{ }^{13} \mathrm{CH}_{15} \mathrm{O}_{3}{ }^{+}$.

Hydrogen-Deuterium exchange reactions using $\mathrm{D}_{2} \mathrm{O}$ were used to confirm the presence of $-\mathrm{OH}$ or - $\mathrm{OOH}$ groups in the products (Table 3). An example of the observed H/D exchange for KHPs, which are the next stable species formed in the cool flame, is given in Figure 2. On can see the formation of the $\mathrm{C}_{7} \mathrm{H}_{13} \mathrm{DO}_{3}{ }^{+}$ion. We proceeded similarly to assess the presence of -OH and -OOH groups in other products (Table 3 ). 
Thanks to the use of UHPLC-MS-MS with APCI (+/-) we could separate and characterize the KHP isomers (Fig. 3). Their chemical structure is given in Table 2 and the solvent gradient used is given in the Supporting Material 1 (Table S1).

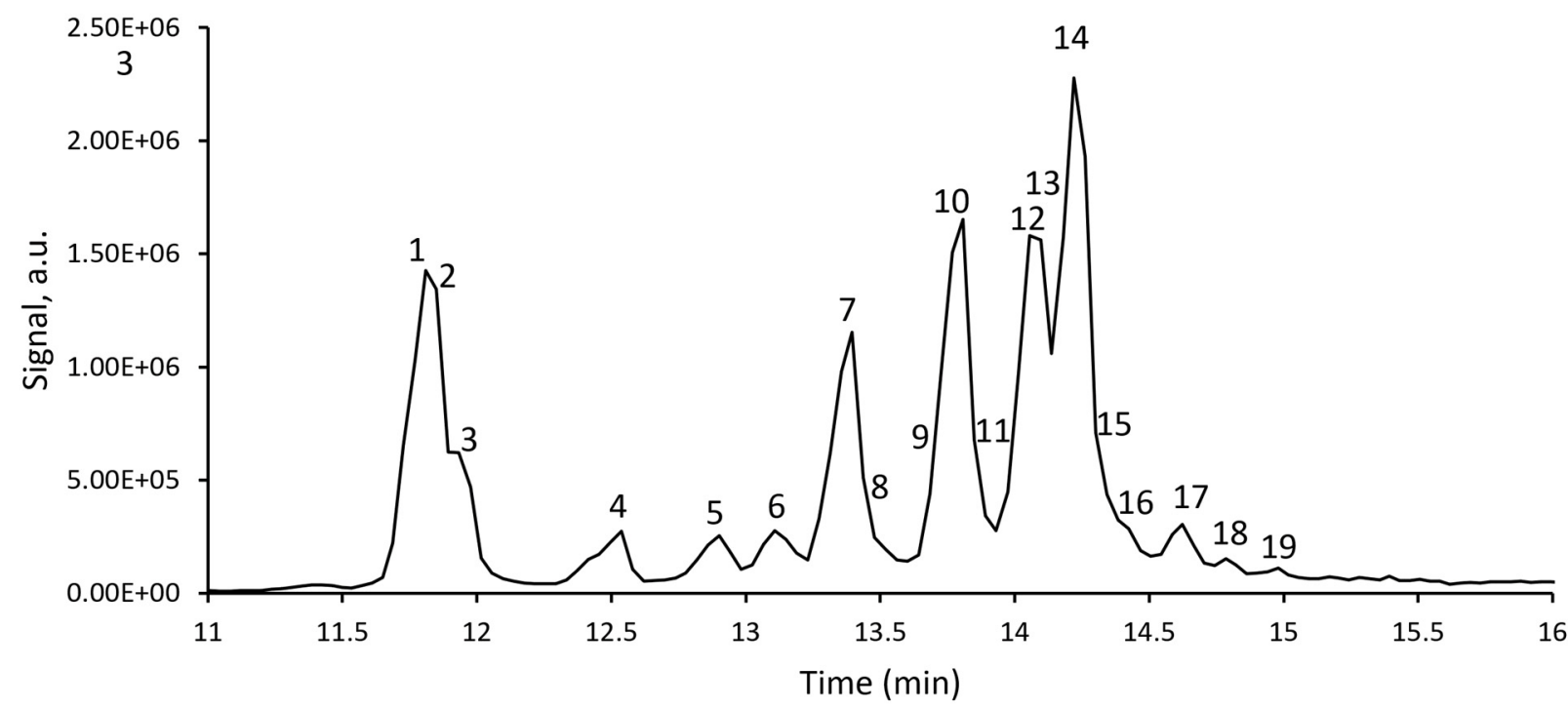

Fig. 3. Chromatographic separation of KHPs isomers $\left(\mathrm{C}_{7} \mathrm{H}_{14} \mathrm{O}_{3}\right)$ obtained by n-heptane oxidation at $640 \mathrm{~K}$. The APCI + mode was used. The structure of the isomers is given in Table 2 .

Using MS/MS, it was possible to identify most of the KHPs formed from the oxidation of n-heptane. Identification of the $\mathrm{C}_{7} \mathrm{H}_{14} \mathrm{O}_{3}$ keto-hydroperoxides isomers was based on the formation of particular fragments in MS/MS analyses. Several isomers may give the same fragment(s). The $\mathrm{C}-\mathrm{C}$ bond cleavage and the relative intensity of the fragments depend on the position of the $-\mathrm{OOH}$ and $=\mathrm{O}$ groups and the distance between them. Thus, several groups of isomers have been defined. A group of isomers with a very specific fragment, $\mathrm{C}_{3} \mathrm{H}_{5} \mathrm{O}_{2}(\mathrm{~m} / \mathrm{z} 73.0283)$ with the highest relative abundance was delineated. $\mathrm{C}_{3} \mathrm{H}_{5} \mathrm{O}_{2}$ is formed when the hydroperoxy and ketone groups are either on carbon \#2 and \#3 or on carbon \#1 and \#2, or carbon \#1 and \#3, followed by a loss of the $=\mathrm{O}$ from the carbonyl group. This characterization is also confirmed by the presence of a $\mathrm{C}_{4} \mathrm{H}_{9}$ fragment $(\mathrm{m} / \mathrm{z} 57.0700)$, corresponding to the other part of $\mathrm{C}_{7} \mathrm{H}_{14} \mathrm{O}_{3}$, at retention times (Rt) $14.62,14.78$, and $14.98 \mathrm{~min}$. This ion is not detected in the fragments of other peaks. Another group consists of isomers giving a $\mathrm{C}_{3} \mathrm{H}_{5} \mathrm{O}$ fragment (m/z 57.0336). This corresponds to fragment having only the ketone function (on carbon \#1, \#2, or \#3). The hydroperoxy group is then systematically found on the other carbon atoms. $\mathrm{C}_{3} \mathrm{H}_{5} \mathrm{O}$ is detected in chromatographic peaks at $\mathrm{Rt} 11.81$ and co-eluted peak at $11.81 \mathrm{~min}$ (relative abundance of 100\%), but also for other isomers with variable percentages. $\mathrm{C}_{4} \mathrm{H}_{7} \mathrm{O}(\mathrm{m} / \mathrm{z} 71.049)$ is characteristic of the presence of the ketone group on one of the carbon atoms of a 44 carbon chain. The hydroperoxy group is then located on other carbon atoms. This fragment has the highest intensity (100\%) at Rt $11.96 \mathrm{~min}$ and with high relative abundance at Rt $12.9 \mathrm{~min}$ (48\%). When the hydroperoxy group is at the end of carbon chain we observed the formation of the $\mathrm{C}_{2} \mathrm{H}_{5} \mathrm{O}_{2}(\mathrm{~m} / \mathrm{z}$ 61.0284) fragment (Rt: co-elution 11.81, 11.96, $12.54,12.90,13.11$, co-elution before $13.81,13.81,14.22$, and $14.62 \mathrm{~min}$ ). Other characteristic fragments allowed distinguishing the different isomers: $\mathrm{C}_{4} \mathrm{H}_{7} \mathrm{O}_{2}(\mathrm{~m} / \mathrm{z}$ 87.0440) is formed when the hydroperoxy and carbonyl groups are on carbon \#1, \#2, \#3, or \#4, followed by a loss of the (=O) group. Similarly, $\mathrm{C}_{5} \mathrm{H}_{9} \mathrm{O}_{2}(\mathrm{~m} / \mathrm{z} 101.0594)$ corresponds to the fragment where the $-\mathrm{OOH}$ and $=\mathrm{O}$ groups are on carbon $\# 1, \# 2, \# 3, \# 4$ or $\# 5$, followed by a loss of $=\mathrm{O}$. 
$\mathrm{C}_{7} \mathrm{H}_{13} \mathrm{O}_{2}(\mathrm{~m} / \mathrm{z} 129,0908)$ is a common fragment for all isomers. It corresponds to the loss of water from $\mathrm{C}_{7} \mathrm{H}_{15} \mathrm{O}_{3}{ }_{3}^{+}$. Its intensity varies with the formation of a hydrogen bond between hydrogen of the $\mathrm{OOH}$ group and the $\mathrm{O}$ of the carbonyl group. Thus, when the $-\mathrm{OOH}$ and $=\mathrm{O}$ groups are close, the probability of hydrogen bond formation increases, making the loss of the $\mathrm{OH}$ difficult. Fragmentation of $\mathrm{C}_{7} \mathrm{H}_{15} \mathrm{O}_{3}{ }^{+}(\mathrm{m} / \mathrm{z}$ 147.1014) generated some fragments that could not be used for the identification of isomers: $\mathrm{C}_{7} \mathrm{H}_{7}(\mathrm{~m} / \mathrm{z} 91.0540)$ Rt 14.62 and 14.78, $\mathrm{C}_{7} \mathrm{H}_{9}$ $\left(\mathrm{m} / \mathrm{z}\right.$ 93.0697) at Rt 11.96 and $12.9, \mathrm{C}_{7} \mathrm{H}_{11} \mathrm{O}(\mathrm{m} / \mathrm{z} 111.0803)$ at Rt 11.96 and $12.9 \mathrm{~min}$; these probably result from intramolecular rearrangements. These results allowed proposing a classification of most KHP isomers according to the presence or absence of characteristic fragments (Table 4). More information is included in Supporting Material 1 (fragments structure is given in Table S2 and relative importance in Table S3) and Supporting Material 2 (MS/MS data).

Table 4. Identification of KHPs by MS/MS: fragments used for chemical structures assignment.

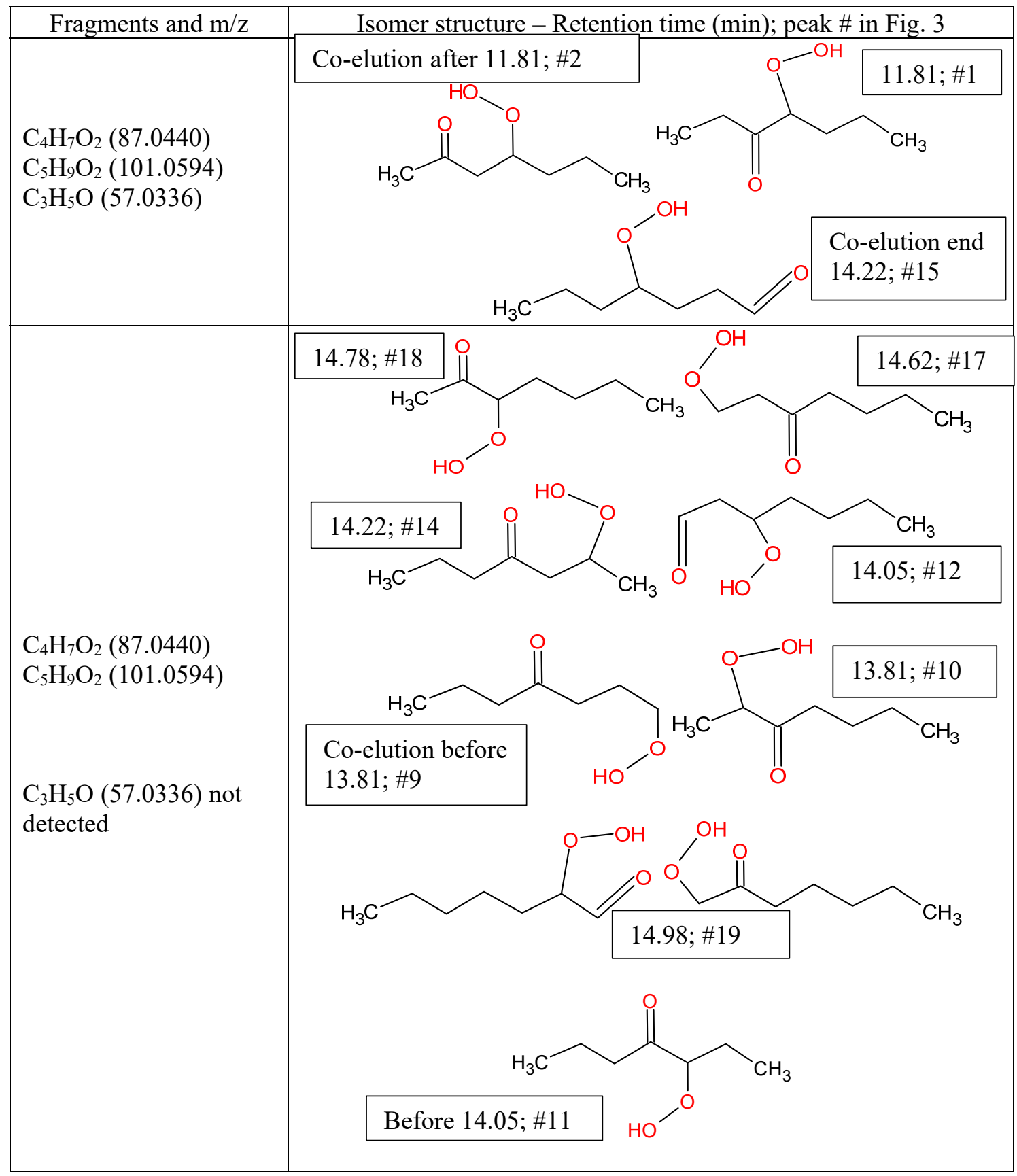




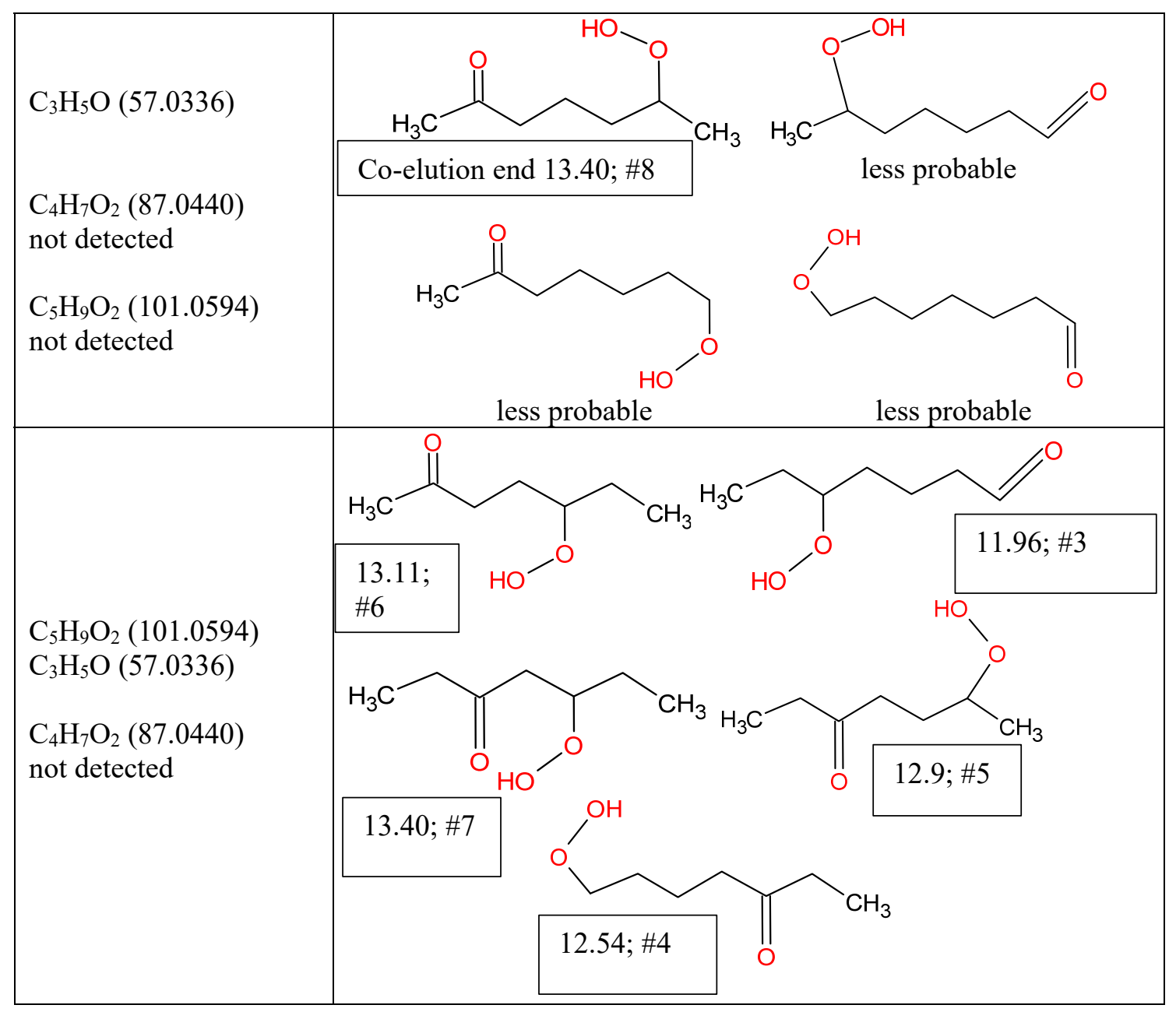

The signal attributed to KHPs sharply increases below the ceiling temperature and peaks at a temperature corresponding to ca. $60 \%$ fuel conversion $(\sim 610 \mathrm{~K})$. This matching is also noticeable in previous JSR experiments performed near atmospheric pressure ( $\sim 550 \mathrm{~K}[45]$ and $\sim 530 \mathrm{~K}[12])$. Three kinetic models were used to simulate the present JSR experiments. Figure 4 shows a comparison of the experimental results $(\mathrm{APCI}+$ ) and chemical kinetic modeling for $n$-heptane and for the sum of KHPs determined under JSR conditions. As can be seen from this figure, the chemical kinetic model of Glaude et al.[36] best predicts the variation of KHPs concentration as a function of temperature in the cool flame regime, although the negative temperature coefficient (NTC) onset is predicted to start at a temperature close to that in the experiments. Also, it is noticeable that the predicted KHPs mole fractions are rather different from one model to another ( $\sim 70-240 \mathrm{ppm})$. 

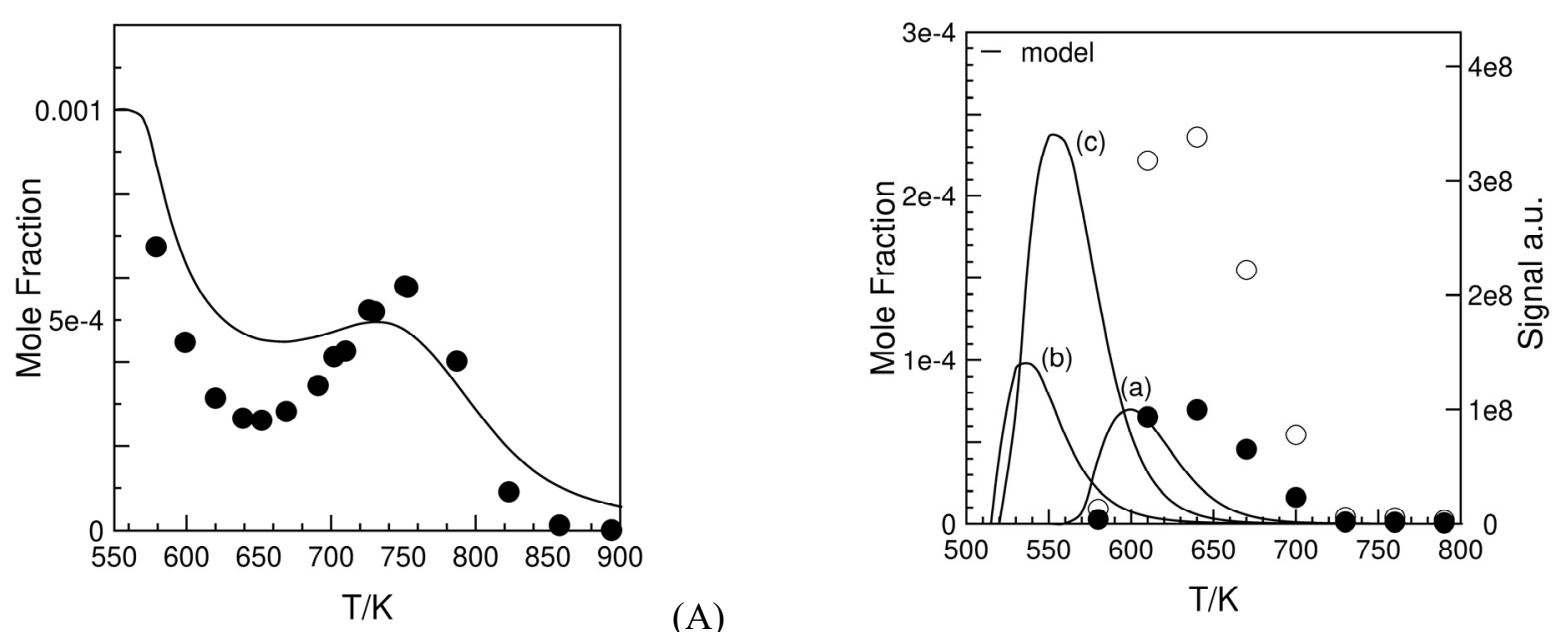

(A)

Fig. 4. Comparison between experimental data (symbols) and modeling (line) for the oxidation of $1000 \mathrm{ppm}$ of $\mathrm{n}$ heptane ( $\varphi=0.5$, residence time of $1 \mathrm{~s}$, and $10 \mathrm{~atm})$. (A) Consumption of n-heptane [9] compared to simulations using Glaude et al. model. (B) Formation of KHPs: comparison of data and modeling using the models of Glaude et al. (a), Mehl et al. (b), and Zhang et al. (c). The data were obtained by integration of UHPLC-MS APCI (+) signal (m/z 147.1015) and scaled to the computed maximum concentration. For convenience, closed symbols are scaled to model (a) and the raw signal intensity is given on the right $\mathrm{Y}$-axis; open symbols are data scaled to model (c). Experimental errors are estimated to be of the order of $40 \%$, as in previous works [41, 42].

The Korcek mechanism [46], which transforms $\gamma$-keto-hydroperoxides into a range of more stable products, namely ketones and acids, can change the global rate of oxidation of the fuel [47]. Grambow et al. [48] in their computational work showed that among 75 possible unimolecular reactions of $C_{3} \gamma$-KHP, the Korcek mechanism had the lowest transition state energy. A range of ketones and carboxylic acids can derive from n-heptane's KHP decomposition, e.g., acetone and butanoic acid, 2-butanone and propanoic acid, 2-pentanone and acetic acid (Fig. 5). These acids were observed in the present experiments (Table 2).

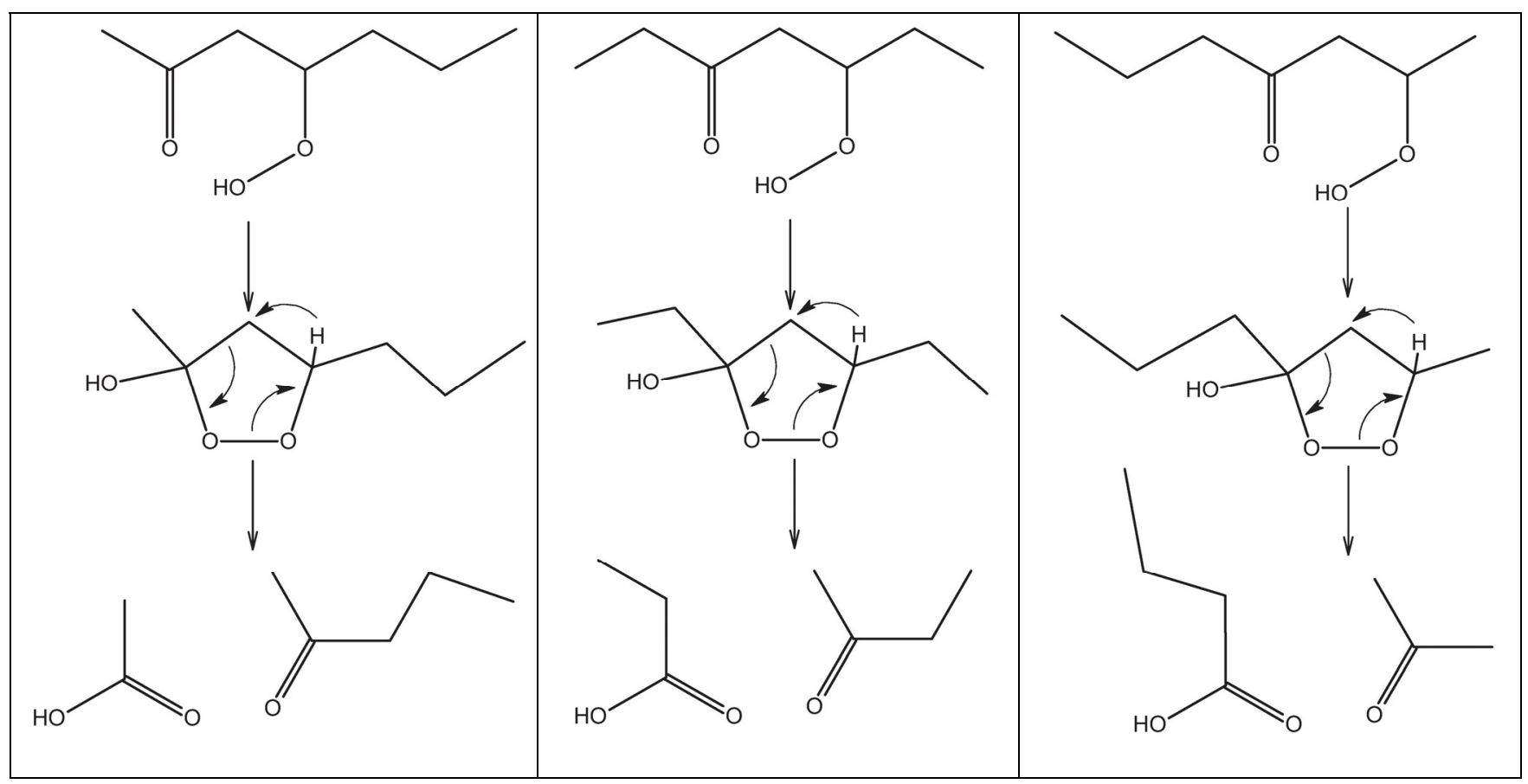


Fig. 5. Formation of carboxylic acids and ketones by decomposition, according to the Korcek mechanism, of most probable n-heptane $\gamma$-keto-hydroperoxides.

Figure 6 shows the formation of acids and ketones observed here as a function of temperature.

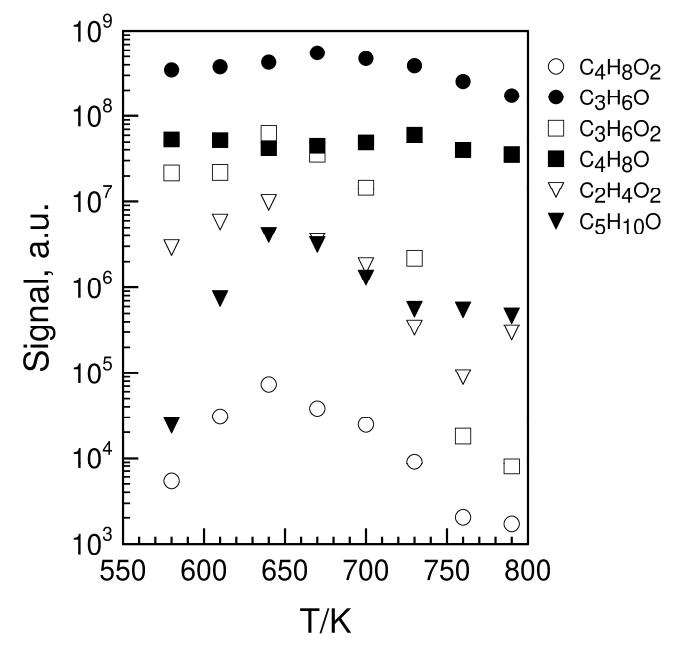

Fig. 6. Formation of acids and ketones which could derive from the Korcek mechanism during the oxidation 1000 ppm of $n$-heptane in a JSR. UHPLC-MS analyses were performed in APCI $(+)$ mode

One can see from Figure 6 that the acid-ketones pairs which could be formed via the Korcek mechanism $\left(\mathrm{C}_{2} \mathrm{H}_{4} \mathrm{O}_{2} / \mathrm{C}_{5} \mathrm{H}_{10} \mathrm{O}, \mathrm{C}_{3} \mathrm{H}_{6} \mathrm{O}_{2} / \mathrm{C}_{4} \mathrm{H}_{8} \mathrm{O}\right.$, and $\left.\mathrm{C}_{4} \mathrm{H}_{8} \mathrm{O}_{2} / \mathrm{C}_{3} \mathrm{H}_{6} \mathrm{O}\right)$ are not in the same order of importance, i.e., $\mathrm{C}_{4} \mathrm{H}_{8} \mathrm{O}_{2}<$ $\mathrm{C}_{2} \mathrm{H}_{4} \mathrm{O}_{2}<\mathrm{C}_{3} \mathrm{H}_{6} \mathrm{O}_{2}$ and $\mathrm{C}_{5} \mathrm{H}_{10} \mathrm{O}<\mathrm{C}_{4} \mathrm{H}_{8} \mathrm{O}<\mathrm{C}_{3} \mathrm{H}_{6} \mathrm{O}$. Also, the peak concentration of acids is not always observed at the same temperature as those for ketones, which is in line with literature data [45]. Because no quantification of these products was performed here, one cannot assess the importance of the Korcek mechanism under the present conditions, but our results seem to indicate the formation of acids and ketones from the Korcek mechanism is not of major importance. In addition to the Korcek mechanism, it has been proposed that carboxylic acids can be produced via other reaction channels [49], e.g., reactions of $\mathrm{CH}_{2} \mathrm{CO}$ to form acetic acid, addition of $\mathrm{OH}$ to $\mathrm{CH}_{2} \mathrm{O}$ producing to formic acid, and decomposition of keto-hydroperoxides cyclic ether.

According to Blin-Simiand et al. [50], diones are produced from the decomposition of KHPs[50] via the sequence of reactions:

$$
\mathrm{R}-\mathrm{C}(=\mathrm{O})-\left(\mathrm{CH}_{2}\right)_{\mathrm{n}}-\mathrm{C}(\mathrm{OOH})-\mathrm{R}^{\prime} \rightarrow \mathrm{OH}^{\bullet}+\mathrm{R}-\mathrm{C}(=\mathrm{O})-\left(\mathrm{CH}_{2}\right)_{\mathrm{n}}-\mathrm{C}(\mathrm{O})-\mathrm{R}^{\prime}
$$

followed by 2 successive isomerization reactions:

$$
\begin{gathered}
\mathrm{R}-\mathrm{C}(=\mathrm{O})-\left(\mathrm{CH}_{2}\right)_{\mathrm{n}}-\mathrm{C}(\mathrm{O})-\mathrm{R}^{\prime} \rightarrow \mathrm{R}_{-\mathrm{H}^{-}} \mathrm{C}(=\mathrm{O})-\left(\mathrm{CH}_{2}\right)_{\mathrm{n}}-\mathrm{C}(\mathrm{OH})-\mathrm{R}^{\prime} \\
\mathrm{R}_{-\mathrm{H}}-\mathrm{C}(=\mathrm{O})-\left(\mathrm{CH}_{2}\right)_{\mathrm{n}}-\mathrm{C}(\mathrm{OH})-\mathrm{R}^{\prime} \rightarrow \mathrm{R}-\mathrm{C}(=\mathrm{O})-\left(\mathrm{CH}_{2}\right)_{\mathrm{n}}-\mathrm{C}^{\bullet}(\mathrm{OH})-\mathrm{R}^{\prime}
\end{gathered}
$$

and addition of $\mathrm{O}_{2}$ followed by $\mathrm{H}$-atom transfer to form the hydroperoxyl radical and a dione:

$$
\begin{aligned}
& \mathrm{R}-\mathrm{C}(=\mathrm{O})-\left(\mathrm{CH}_{2}\right)_{\mathrm{n}}-\mathrm{C}^{\bullet}(\mathrm{OH})-\mathrm{R}^{\prime}+\mathrm{O}_{2} \rightarrow \mathrm{R}-\mathrm{C}(=\mathrm{O})-\left(\mathrm{CH}_{2}\right)_{\mathrm{n}}-\mathrm{C}\left(\mathrm{OO}^{\bullet}\right)(\mathrm{OH})-\mathrm{R}^{\prime} \\
& \mathrm{R}-\mathrm{C}(=\mathrm{O})-\left(\mathrm{CH}_{2}\right)_{\mathrm{n}}-\mathrm{C}(\mathrm{OO} \bullet)(\mathrm{OH})-\mathrm{R}^{\prime} \rightarrow \mathrm{R}-\mathrm{C}(=\mathrm{O})-\left(\mathrm{CH}_{2}\right)_{\mathrm{n}}-\mathrm{C}(\mathrm{OOH})\left(\mathrm{O}^{\bullet}\right)-\mathrm{R}^{\prime} \\
& \mathrm{R}-\mathrm{C}(=\mathrm{O})-\left(\mathrm{CH}_{2}\right)_{\mathrm{n}}-\mathrm{C}(\mathrm{OOH})\left(\mathrm{O}^{\bullet}\right)-\mathrm{R}^{\prime} \rightarrow \mathrm{HO}_{2}+\mathrm{R}-\mathrm{C}(=\mathrm{O})-\left(\mathrm{CH}_{2}\right)_{\mathrm{n}}-\mathrm{C}(=\mathrm{O})-\mathrm{R}^{\prime} .
\end{aligned}
$$


Other pathways have been proposed, e. g., Pelucchi et al. [51] proposed that diones are directly produced by H-atom abstraction on KHPs:

$$
\mathrm{R}^{\bullet}+\mathrm{C}_{7} \mathrm{H}_{14} \mathrm{O}_{3}{ }^{\mathrm{i}, \mathrm{j}} \rightarrow \mathrm{RH}+\mathrm{C}_{7} \mathrm{H}_{12} \mathrm{O}_{2}{ }^{\mathrm{i}, \mathrm{j}}+\mathrm{OH}^{\bullet}
$$

where $i, j$ are the positions of carbonyl and $\mathrm{OOH}$ groups in KHPs. Other pathways including roaming reaction of KHPs [52] to produce dione and water, and decomposition of ${ }^{\bullet} \mathrm{OOQOOH}[53]$ have been proposed.

Several diones were observed in the present study using UHPLC-MS analyses. Figure 7a shows the variation of the MS signal at m/z 129.0907 as a function of temperature. As observed for several other cool flame products, the production of diones reaches a maximum around $640 \mathrm{~K}$.

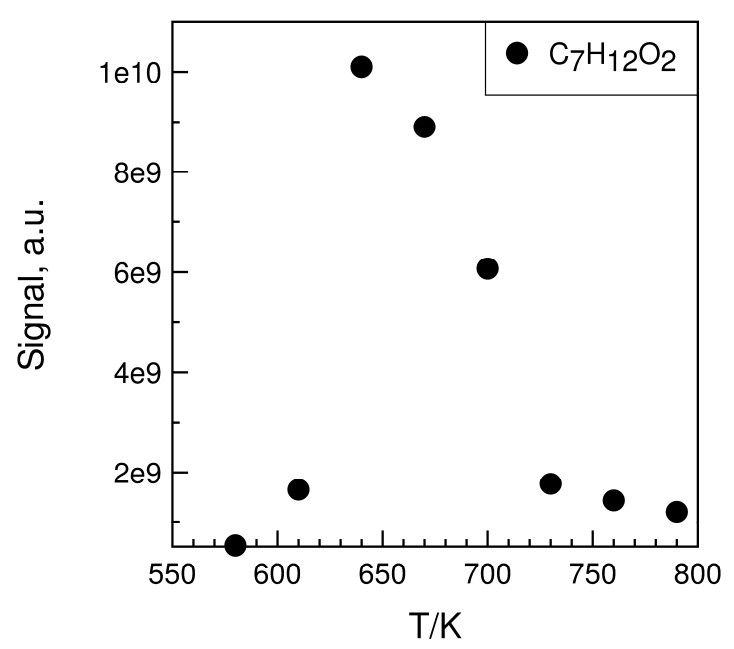

(a)

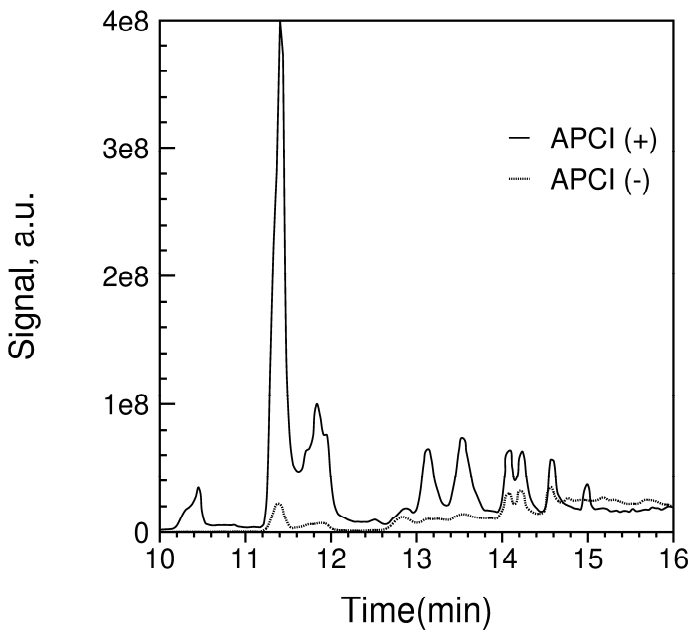

(b)

Fig. 7. Formation of diones during the oxidation $1000 \mathrm{ppm}$ of n-heptane in a JSR. (a) Analyses were performed in APCI $(+)$ mode $\left(\mathrm{m} / \mathrm{z}\right.$ 129.0907, $\left.\mathrm{C}_{7} \mathrm{H}_{13} \mathrm{O}_{2}{ }^{+}\right)$; (b) chromatogram showing different isomers in APCI $(+)$, full line and APCI (-), dotted line (T=640 K).

A range of cyclic ethers can be formed in the NTC region during n-heptane oxidation [45, 54, 55]. They are produced by decomposition of QOOH: QOOH $\rightarrow$ cyclic ether $+\mathrm{OH}$. This class of compounds was observed in the present work (Fig. 8).
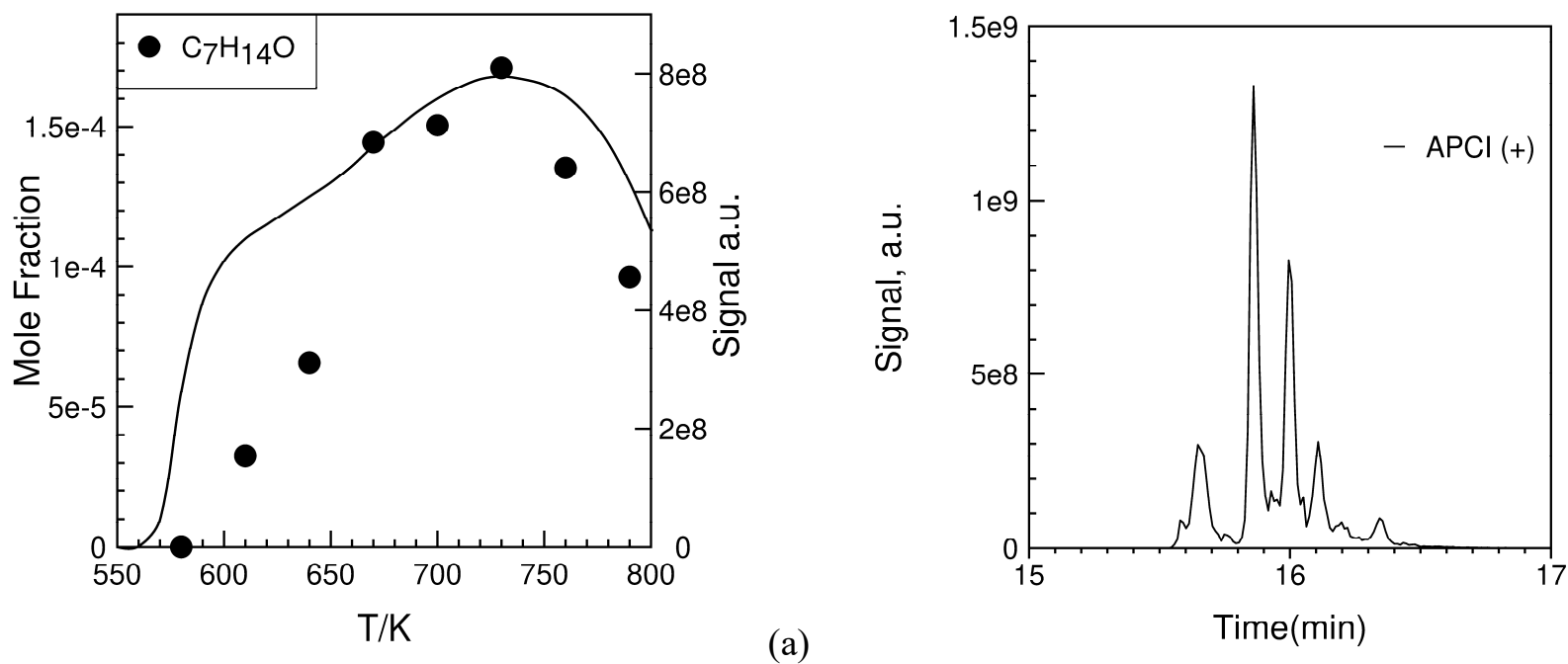

(a)

(b) 
Fig. 8. Formation of cyclic ethers during the oxidation $1000 \mathrm{ppm}$ of $\mathrm{n}$-heptane in a JSR. Analyses were performed in APCI $(+)$ mode $\left(\mathrm{m} / \mathrm{z} 115.1116, \mathrm{C}_{7} \mathrm{H}_{15} \mathrm{O}^{+}\right)$: (a) Integrated signal (symbols) compared to modeling results (line) using the total mole fractions of $\mathrm{C}_{7}$ ethers. For convenience, the raw data are scaled to modeling results [36]. The raw signal intensity is given on the right $\mathrm{Y}$-axis. Experimental errors are estimated to be of the order of $40 \%$, as in previous works [41, 42]. (b) UHPLC APCI (+) chromatogram showing different isomers formed at $730 \mathrm{~K}$.

In APCI (-), ethers were not ionized. Therefore, the recorded APCI (-) signal was most likely due to isomers (aldehydes and ketones). In APCI (+), ethers are ionized; the recorded MS signal was $\sim 100$ times higher than in APCI (-), and most likely mainly due to cyclic ethers. As can be seen from Figure 8, the MS signal (m/z 115.1116, $\left.\mathrm{C}_{7} \mathrm{H}_{15} \mathrm{O}^{+}\right)$reaches a maximum around $700 \mathrm{~K}(60 \%$ fuel conversion in the NTC), which is in line with earlier observations $[10,55]$ made using GC/MS and GC-FID analyses of gas samples collected during the oxidation in a JSR of 500-1000 ppm of a n-heptane and $1000 \mathrm{ppm}$ of n-heptane/iso-octane (90:10) mixture, respectively. This is also what can be observed from other experiments performed in JSR near atmospheric pressure ( $\sim 670 \mathrm{~K}$ for both maximum ethers mole fraction and 60\% fuel conversion in the NTC)[45]. Finally, one can see from Fig. 8 that the model of Glaude et al. [36] gives a reasonable representation of the scaled data, although $\mathrm{C}_{7}$ ethers formation below $670 \mathrm{~K}$ seems overestimated.

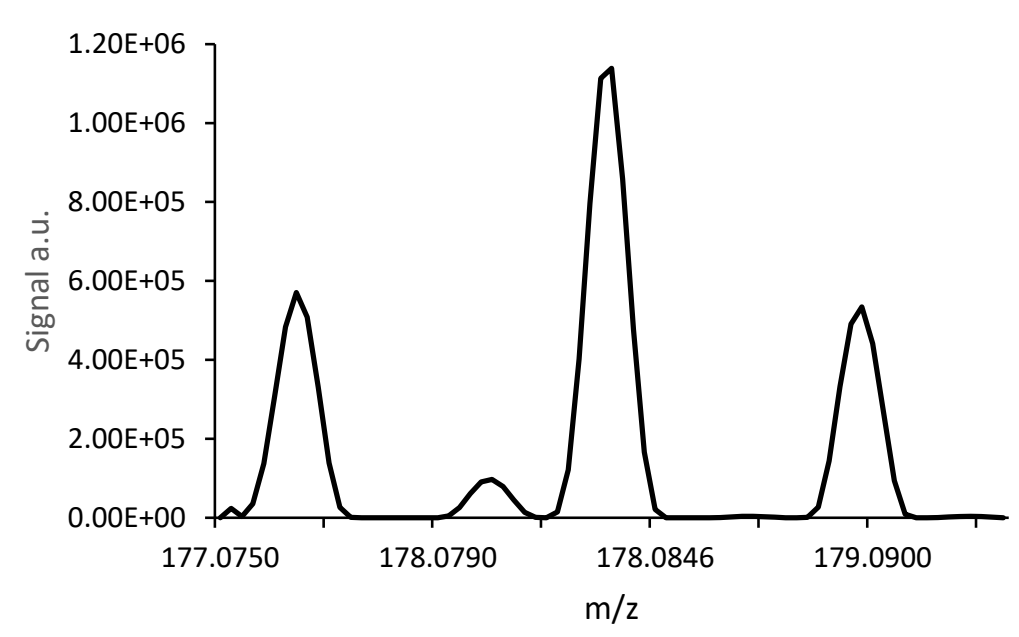

Fig. 9. Mass spectrum showing the increased signal of $\mathrm{C}_{7} \mathrm{H}_{12} \mathrm{DO}_{5}{ }^{-}$and $\mathrm{C}_{7} \mathrm{H}_{11} \mathrm{D}_{2} \mathrm{O}_{5}{ }^{-}$vs. $\mathrm{C}_{7} \mathrm{H}_{13} \mathrm{O}_{5}{ }^{-}$due to OH/OD exchange on HOMs. Only $\mathrm{C}_{7} \mathrm{H}_{13} \mathrm{O}_{3}{ }^{-}$could be observed without addition of $\mathrm{D}_{2} \mathrm{O}$. Analyses were performed in FIA APCI (-) using the concentrated ( $80 \%$ evaporated) sample obtained by oxidation of n-heptane at $640 \mathrm{~K}$. The signal at $\mathrm{m} / \mathrm{z} 178.0803$ corresponds to $\mathrm{C}_{6}{ }^{13} \mathrm{CH}_{13} \mathrm{O}_{5}$. 


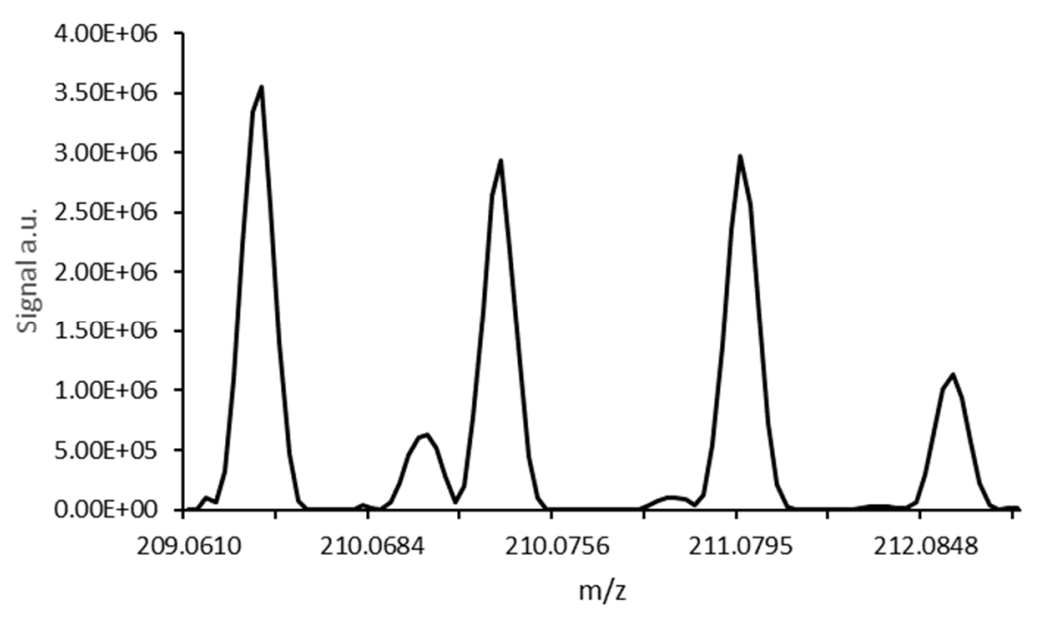

Fig. 10. Mass spectrum showing the increased signal of $\mathrm{C}_{7} \mathrm{H}_{12} \mathrm{DO}_{7}^{-}, \mathrm{C}_{7} \mathrm{H}_{11} \mathrm{D}_{2} \mathrm{O}_{7}^{-}$, and $\mathrm{C}_{7} \mathrm{H}_{10} \mathrm{D}_{3} \mathrm{O}_{7}^{-}$vs. $\mathrm{C}_{7} \mathrm{H}_{13} \mathrm{O}_{7}^{-}$due to 1,2 , and $3 \mathrm{OH} / \mathrm{OD}$ exchanges on HOMs. Only $\mathrm{C}_{7} \mathrm{H}_{13} \mathrm{O}_{7}{ }^{-}$could be observed without addition of $\mathrm{D}_{2} \mathrm{O}$. Analyses were performed in FIA APCI (-) using the concentrated ( $80 \%$ evaporated) sample obtained by oxidation of $\mathrm{n}$ heptane at $640 \mathrm{~K}$. The small signals at $\mathrm{m} / \mathrm{z} 210.0704, \mathrm{~m} / \mathrm{z} 211.0769$, and $\mathrm{m} / \mathrm{z} 212.0831$ correspond to ions $\mathrm{C}_{6}{ }^{13} \mathrm{CH}_{13} \mathrm{O}_{7}, \mathrm{C}_{6}{ }^{13} \mathrm{CH}_{12} \mathrm{DO}_{7}$, and $\mathrm{C}_{6}{ }^{13} \mathrm{CH}_{11} \mathrm{D}_{2} \mathrm{O}_{7}$, respectively.

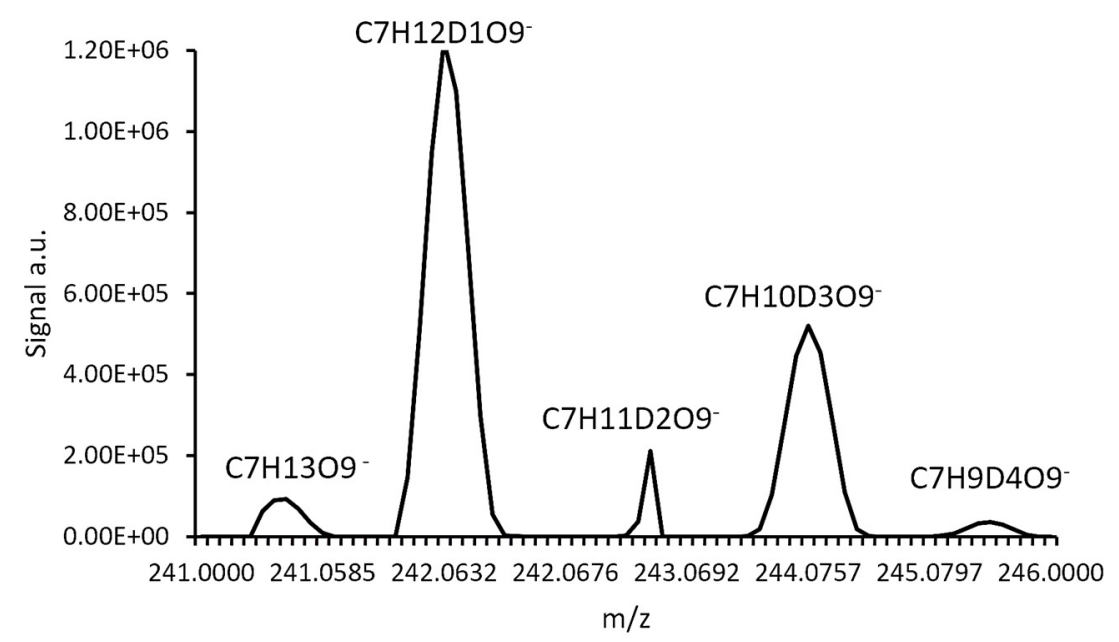

Fig. 11; Mass spectrum showing the appearance of signal for $\mathrm{C}_{7} \mathrm{H}_{12} \mathrm{DO}_{9}{ }^{-}$and $\mathrm{C}_{7} \mathrm{H}_{11} \mathrm{D}_{2} \mathrm{O}_{9}{ }^{-}$, in addition to that for $\mathrm{C}_{7} \mathrm{H}_{13} \mathrm{O}_{9}{ }^{-}$, due to $\mathrm{OH} / \mathrm{OD}$ exchange on HOMs. Only $\mathrm{C}_{7} \mathrm{H}_{13} \mathrm{O}_{9}{ }^{-}$could be observed without addition of $\mathrm{D}_{2} \mathrm{O}$.

Analyses were performed in FIA APCI (-) using the concentrated ( $80 \%$ evaporated) sample obtained by oxidation of n-heptane at $640 \mathrm{~K}$.

Highly oxygenated molecules (MW 176-274), which derive from further peroxidation, were also observed (Table 3). $\mathrm{OH} / \mathrm{OD}$ exchange was used to assess the presence of multiple -OOH groups (Figs. 9-11). These products resulted from up to 6 additions of $\mathrm{O}_{2}$ on fuel's radicals. Among these species, one founds unsaturated KHPs (MW 176), keto-dihydroperoxides (MW 178), di-keto-di-hydroperoxides (MW 192), di-keto-tri-hydroperoxides (MW 210), keto-tetra-hydroperoxides (MW 242), and keto-penta-hydroperoxides (MW 274), all reported for the first time as products of n-heptane oxidation.

\section{Conclusion and Perspectives}


The oxidation of $\mathrm{n}$-heptane was performed in a jet-stirred reactor ( $10 \mathrm{~atm}, 580-790 \mathrm{~K}$, equivalence ratios of 0.5 and initial fuel concentration of $1000 \mathrm{ppm}$ and $5000 \mathrm{ppm}$ ). Low-temperature products formed in JSR experiments were characterized by collecting samples dissolved in acetonitrile and analyzed using a range of techniques (flow injection analyses, UHPLC analyses, high resolution mass spectrometry with APCI (+) and (-), and MS-MS). The present analyses allowed characterizing hydroperoxides $\left(\mathrm{C}_{7} \mathrm{H}_{16} \mathrm{O}_{2}\right)$, keto-hydroperoxides $\left(\mathrm{C}_{7} \mathrm{H}_{14} \mathrm{O}_{3}\right)$, carboxylic acids $\left(\mathrm{C}_{2} \mathrm{H}_{4} \mathrm{O}_{2}, \mathrm{C}_{3} \mathrm{H}_{6} \mathrm{O}_{2}, \mathrm{C}_{4} \mathrm{H}_{8} \mathrm{O}_{2}, \mathrm{C}_{5} \mathrm{H}_{10} \mathrm{O}_{2}, \mathrm{C}_{6} \mathrm{H}_{12} \mathrm{O}_{2}, \mathrm{C}_{7} \mathrm{H}_{14} \mathrm{O}_{2}\right)$, diones $\left(\mathrm{C}_{7} \mathrm{H}_{12} \mathrm{O}_{2}\right)$, and highly oxygenated molecules (MW 162-274, i.e., $\mathrm{C}_{7} \mathrm{H}_{14} \mathrm{O}_{4}$ to $\mathrm{C}_{7} \mathrm{H}_{114} \mathrm{O}_{11}$ ) resulting from the addition of up to six $\mathrm{O}_{2}$ molecules on fuel's radicals. Also, cyclic ethers were observed. To confirm the presence of $-\mathrm{OH}$ or $-\mathrm{OOH}$ groups in n-heptane oxidation products $\mathrm{H} / \mathrm{D}$ exchange with $\mathrm{D}_{2} \mathrm{O}$ was used. MS-MS analyses were used to identify the KHPs isomers.

Many of the newly detected species are not included in available reaction schemes for n-heptane oxidation. Their inclusion in detailed reaction mechanisms could be of interest for improving them. Further experiments using RCM and IC engines, and analyses of the exhaust should be useful for assessing the importance of the lowtemperature chemistry observed in this study under more practical conditions.

\section{Acknowledgements}

The authors gratefully acknowledge funding from the Labex Caprysses (convention ANR-11-LABX-0006-01) and from the Région Centre Val de Loire, EFRD, and CPER (projects PROMESTOCK and APROPOR-E).

\section{References}

[1] P. Dagaut; M. Cathonnet, The ignition, oxidation, and combustion of kerosene: A review of experimental and kinetic modeling, Prog. Energy Combust. Sci. 32 (1) (2006) 48-92.

[2] W. J. Pitz; C. J. Mueller, Recent progress in the development of diesel surrogate fuels, Prog. Energy Combust. Sci. 37 (3) (2011) 330-350.

[3] P. Dagaut, On the kinetics of hydrocarbons oxidation from natural gas to kerosene and diesel fuel, Phys. Chem. Chem. Phys. 4 (11) (2002) 2079-2094.

[4] J. K. Shao; R. Choudhary; Y. Z. Peng; D. F. Davidson; R. K. Hanson, A shock tube study of n-heptane, iso-octane, ndodecane and iso-octane/n-dodecane blends oxidation at elevated pressures and intermediate temperatures, Fuel 243 (2019) 541-553.

[5] X. L. Han; Z. H. Wang; Y. He; S. X. Wang; Y. Z. Liu; A. A. Konnov, Temperature dependence of the laminar burning velocity for n-heptane and iso-octane/air flames, Fuel 276 (2020)

[6] A. M. Ferris; A. J. Susa; D. F. Davidson; R. K. Hanson, A comparative laser absorption and gas chromatography study of low-temperature n-heptane oxidation intermediates, Proc. Combust. Inst. 37 (1) (2019) 249-257.

[7] M. F. Campbell; S. Wang; D. F. Davidson; R. K. Hanson, Shock tube study of normal heptane first-stage ignition near 3.5 atm, Combust. Flame 198 (2018) 376-392.

[8] F. L. Dryer; K. Brezinsky, A flow reactor study of the oxidation of normal-octane and isooctane, Combust. Sci. Technol. 45 (3-4) (1986) 199-212.

[9] P. Dagaut; M. Reuillon; M. Cathonnet, High-Pressure Oxidation of Liquid Fuels from Low to High-Temperature .1. NHeptane and Isooctane, Combust. Sci. Technol. 95 (1-6) (1994) 233-260.

[10] P. Dagaut; M. Reuillon; M. Cathonnet, Experimental-Study of the Oxidation of N-Heptane in a Jet-Stirred Reactor from Low-Temperature to High-Temperature and Pressures up to 40-Atm, Combust. Flame 101 (1-2) (1995) 132-140. 
[11] P. Dagaut; R. Koch; M. Cathonnet, The oxidation of n-heptane in the presence of oxygenated octane improvers: MTBE and ETBE, Combust. Sci. Technol. 122 (1-6) (1997) 345-361.

[12] Z. D. Wang; B. J. Chen; K. Moshammer; D. M. Popolan-Vaida; S. Sioud; V. S. B. Shankar; D. Vuilleumier; T. Tao; L. Ruwe; E. Brauer; N. Hansen; P. Dagaut; K. Kohse-Hoinghaus; M. A. Raji; S. M. Sarathy, n-Heptane cool flame chemistry: Unraveling intermediate species measured in a stirred reactor and motored engine, Combust. Flame 187 (2018) $199-216$.

[13] C. Doute; J. L. Delfau; R. Akrich; C. Vovelle, Experimental study of the chemical structure of low-pressure premixed nheptane-O-2-Ar and iso-octane-O-2-Ar flames, Combust. Sci. Technol. 124 (1997) 249-276.

[14] A. E. Bakali; J. L. Delfau; C. Vovelle, Experimental study of 1 atmosphere, rich, premixed n-heptane and iso-octane flames, Combust. Sci. Technol. 140 (1998) 69-91.

[15] A. Elbakali; J. L. Delfau; C. Vovelle, Kinetic modeling of a rich, atmospheric pressure, premixed n-heptane/O-2/N-2 flame, Combust. Flame 118 (3) (1999) 381-398.

[16] L. Seidel; K. Moshammer; X. X. Wang; T. Zeuch; K. Kohse-Hoinghaus; F. Mauss, Comprehensive kinetic modeling and experimental study of a fuel-rich, premixed n-heptane flame, Combust. Flame 162 (5) (2015) 2045-2058.

[17] P. Berta; I. K. Puri; S. K. Aggarwal, Structure of partially premixed n-heptane-air counterflow flames, Proc. Combust. Inst. 30 (2005) 447-453.

[18] R. Minetti; M. Carlier; M. Ribaucour; E. Therssen; L. R. Sochet, A rapid compression machine investigation of oxidation and auto-ignition of n-heptane: Measurements and modeling, Combust. Flame 102 (3) (1995) 298-309.

[19] K. A. Sahetchian; R. Rigny; S. Circan, Identification of the hydroperoxide formed by isomerization reactions during the oxidation of n-heptane in a reactor and CFR engine, Combust. Flame 85 (3-4) (1991) 511-514.

[20] O. Perrin; A. Heiss; K. Sahetchian; L. Kerhoas; J. Einhorn, Determination of the isomerization rate constant $\mathrm{HOCH} 2 \mathrm{CH} 2 \mathrm{CH} 2 \mathrm{CH}(\mathrm{OO}$ center dot $) \mathrm{CH} 3->(\mathrm{HOCHCH} 2 \mathrm{CH} 2 \mathrm{CH})-\mathrm{H}$-center $\operatorname{dot}(\mathrm{OOH}) \mathrm{CH} 3$. Importance of intramolecular hydroperoxy isomerization in tropospheric chemistry, Int. J. Chem. Kinet. 30 (12) (1998) 875-887.

[21] N. Blin-Simiand; F. Jorand; K. Keller; M. Fiderer; K. Sahetchian, Ketohydroperoxides and ignition delay in internal combustion engines, Combust. Flame 112 (1998) 278-282.

[22] A. Heiss; K. Sahetchian, Isomerization reactions of the n-C4H9O and n-OOC4H8OH radicals in oxygen, Int. J. Chem. Kinet. 28 (7) (1996) 531-544.

[23] K. Sahetchian; J. C. Champoussin; M. Brun; N. Levy; N. Blin-Simiand; C. Aligrot; F. Jorand; M. Socoliuc; A. Heiss; N. Guerassi, Experimental study and modeling of dodecane ignition in a diesel engine, Combust. Flame 103 (3) (1995) $207-220$.

[24] M. Zinbo; R. K. Jensen; S. Korcek, Gas-liquid-chromatography of oxygenated compounds related to autoxidation of nhexadecane, Anal. Lett. 10 (2) (1977) 119-132.

[25] R. K. Jensen; S. Korcek; L. R. Mahoney; M. Zinbo, Liquid-phase autoxidation of organic-compounds at elevatedtemperatures .1. stirred flow reactor technique and analysis of primary products from normal-hexadecane autoxidation at 120degrees-C 180-degrees-C, J. Am. Chem. Soc. 101 (25) (1979) 7574-7584.

[26] R. K. Jensen; S. Korcek; L. R. Mahoney; M. Zinbo, Liquid-phase autoxidation of organic-compounds at elevatedtemperatures .2. Kinetics and mechanisms of the formation of cleavage products in normal-hexadecane autoxidation, J. Am. Chem. Soc. 103 (7) (1981) 1742-1749.

[27] R. K. Jensen; M. Zinbo; S. Korcek, HPLC determination of hydroperoxidic products formed in the autoxidation of normalhexadecane at elevated-temperatures, J. Chromatogr. Sci. 21 (9) (1983) 394-397.

[28] R. K. Jensen; S. Korcek; M. Zinbo, Formation, isomerization, and cyclization reactions of hydroperoxyalkyl radicals in hexadecane autoxidation at 160-190-degrees-C, J. Am. Chem. Soc. 114 (20) (1992) 7742-7748.

[29] Z. Wang; D. M. Popolan-Vaida; B. Chen; K. Moshammer; S. Y. Mohamed; H. Wang; S. Sioud; M. A. Raji; K. KohseHöinghaus; N. Hansen; P. Dagaut; S. R. Leone; S. M. Sarathy, Unraveling the structure and chemical mechanisms of highly 
oxygenated intermediates in oxidation of organic compounds, Proceedings of the National Academy of Sciences 114 (50) (2017) 13102-13107.

[30] F. Bianchi; T. Kurtén; M. Riva; C. Mohr; M. P. Rissanen; P. Roldin; T. Berndt; J. D. Crounse; P. O. Wennberg; T. F. Mentel; J. Wildt; H. Junninen; T. Jokinen; M. Kulmala; D. R. Worsnop; J. A. Thornton; N. Donahue; H. G. Kjaergaard; M. Ehn, Highly Oxygenated Organic Molecules (HOM) from Gas-Phase Autoxidation Involving Peroxy Radicals: A Key Contributor to Atmospheric Aerosol, Chemical Reviews 119 (6) (2019) 3472-3509.

[31] K. Moshammer; A. W. Jasper; D. M. Popolan-Vaida; A. Lucassen; P. Dievart; H. Selim; A. J. Eskola; C. A. Taatjes; S. R. Leone; S. M. Sarathy; Y. G. Ju; P. Dagaut; K. Kohse-Hoinghaus; N. Hansen, Detection and Identification of the KetoHydroperoxide (HOOCH2OCHO) and Other Intermediates during Low-Temperature Oxidation of Dimethyl Ether, J. Phys. Chem. A 119 (28) (2015) 7361-7374.

[32] K. Moshammer; A. W. Jasper; D. M. Popolan-Vaida; Z. D. Wang; V. S. B. Shankar; L. Ruwe; C. A. Taatjes; P. Dagaut; N. Hansen, Quantification of the Keto-Hydroperoxide (HOOCH2OCHO) and Other Elusive Intermediates during LowTemperature Oxidation of Dimethyl Ether, J. Phys. Chem. A 120 (40) (2016) 7890-7901.

[33] P. Dagaut; N. Belhadj; R. Benoit; G. Dayma; M. Lailliau; Z. Serinyel, in: MCS11 11th Mediterranean Combustion Symposium https://hal.archives-ouvertes.fr/hal-02137413, Tenerife, Spain, 2019.

[34] K. W. Zhang; C. Banyon; J. Bugler; H. J. Curran; A. Rodriguez; O. Herbinet; F. Battin-Leclerc; C. B'Chir; K. A. Heufer, An updated experimental and kinetic modeling study of n-heptane oxidation, Combust. Flame 172 (2016) 116-135.

[35] M. Mehl; W. J. Pitz; C. K. Westbrook; H. J. Curran, Kinetic modeling of gasoline surrogate components and mixtures under engine conditions, Proc. Combust. Inst. 33 (1) (2011) 193-200.

[36] P. A. Glaude; V. Conraud; R. Fournet; F. Battin-Leclerc; G. M. Come; G. Scacchi; P. Dagaut; M. Cathonnet, Modeling the oxidation of mixtures of primary reference automobile fuels, Energy Fuels 16 (5) (2002) 1186-1195.

[37] P. Dagaut; M. Cathonnet; J. P. Rouan; R. Foulatier; A. Quilgars; J. C. Boettner; F. Gaillard; H. James, A Jet-Stirred Reactor for Kinetic-Studies of Homogeneous Gas-Phase Reactions at Pressures up to 10-Atmospheres ( $1 \mathrm{MPa})$, Journal of Physics E-Scientific Instruments 19 (3) (1986) 207-209.

[38] A. El Bakali; P. Dagaut; L. Pillier; P. Desgroux; J. F. Pauwels; A. Rida; P. Meunier, Experimental and modeling study of the oxidation of natural gas in a premixed flame, shock tube, and jet-stirred reactor, Combust. Flame 137 (1-2) (2004) 109128 .

[39] T. Le Cong; P. Dagaut, Experimental and Detailed Modeling Study of the Effect of Water Vapor on the Kinetics of Combustion of Hydrogen and Natural Gas, Impact on NOx, Energy Fuels 23 (1) (2009) 725-734.

[40] S. Thion; C. Togbe; Z. Serinyel; G. Dayma; P. Dagaut, A chemical kinetic study of the oxidation of dibutyl-ether in a jetstirred reactor, Combust. Flame 185 (2017) 4-15.

[41] N. Belhadj; R. Benoit; P. Dagaut; M. Lailliau; Z. Serinyel; G. Dayma; F. Khaled; B. Moreau; F. Foucher, Oxidation of di-n-butyl ether: Experimental characterization of low-temperature products in JSR and RCM, Combust. Flame 222 (2020) $133-144$.

[42] N. Belhadj; R. Benoit; P. Dagaut; M. Lailliau; Z. Serinyel; G. Dayma, Oxidation of di-n-propyl ether: Characterization of low-temperature products, Proc. Combust. Inst. 38 (2021) https://doi.org/10.1016/j.proci.2020.06.350.

[43] P. Glarborg; R. J. Kee; J. F. Grcar; J. A. Miller in: PSR: A FORTRAN program for modeling well-stirred reactors., SAND86-8209, Sandia National Laboratories, Livermore, CA, 1986

[44] R. J. Kee; F. M. Rupley; J. A. Miller in: CHEMKIN-II: A Fortran Chemical Kinetics Package for the Analysis of GasPhase Chemical Kinetics., SAND89-8009, Sandia National Laboratories, Livermore, CA, 1989 
[45] O. Herbinet; B. Husson; Z. Serinyel; M. Cord; V. Warth; R. Fournet; P. A. Glaude; B. Sirjean; F. Battin-Leclerc; Z. D. Wang; M. F. Xie; Z. J. Cheng; F. Qi, Experimental and modeling investigation of the low-temperature oxidation of n-heptane, Combust. Flame 159 (12) (2012) 3455-3471.

[46] A. Jalan; I. M. Alecu; R. Meana-Paneda; J. Aguilera-Iparraguirre; K. R. Yang; S. S. Merchant; D. G. Truhlar; W. H. Green, New Pathways for Formation of Acids and Carbonyl Products in Low-Temperature Oxidation: The Korcek Decomposition of gamma-Ketohydroperoxides, J. Am. Chem. Soc. 135 (30) (2013) 11100-11114.

[47] Z. D. Wang; S. M. Sarathy, Third O-2 addition reactions promote the low-temperature auto-ignition of n-alkanes, Combust. Flame 165 (2016) 364-372.

[48] C. A. Grambow; A. Jamal; Y. P. Li; W. H. Green; J. Zador; Y. V. Suleimanov, Unimolecular Reaction Pathways of a gamma-Ketohydroperoxide from Combined Application of Automated Reaction Discovery Methods, J. Am. Chem. Soc. 140 (3) (2018) 1035-1048.

[49] F. Battin-Leclerc; A. A. Konnov; J. L. Jaffrezo; M. Legrand, To better understand the formation of short-chain acids in combustion systems, Combust. Sci. Technol. 180 (2) (2008) 343-370.

[50] N. Blin-Simiand; F. Jorand; K. Sahetchian; M. Brun; L. Kerhoas; C. Malosse; J. Einhorn, Hydroperoxides with zero, one, two or more carbonyl groups formed during the oxidation of n-dodecane, Combust. Flame 126 (1) (2001) 1524-1532.

[51] M. Pelucchi; M. Bissoli; C. Cavallotti; A. Cuoci; T. Faravelli; A. Frassoldati; E. Ranzi; A. Stagni, Improved Kinetic Model of the Low-Temperature Oxidation of n-Heptane, Energy Fuels 28 (11) (2014) 7178-7193.

[52] R. H. West; C. F. Goldsmith, The impact of roaming radicals on the combustion properties of transportation fuels, Combust. Flame 194 (2018) 387-395.

[53] A. J. Eskola; I. O. Antonov; L. Sheps; J. D. Savee; D. L. Osborn; C. A. Taatjes, Time-resolved measurements of product formation in the low-temperature $(550-675 \mathrm{~K})$ oxidation of neopentane: a probe to investigate chain-branching mechanism, Phys. Chem. Chem. Phys. 21 (2017) 13731-13745.

[54] P. Dagaut; M. Reuillon; M. Cathonnet; D. Presvots, Gas-Chromatography and Mass-Spectrometry Identification of Cyclic Ethers Formed from Reference Fuels Combustion, Chromatographia 40 (3-4) (1995) 147-154.

[55] P. Dagaut; M. Reuillon; M. Cathonnet, High-Pressure Oxidation of Liquid Fuels from Low to High-Temperature .2. Mixtures of N-Heptane and Isooctane, Combust. Sci. Technol. 103 (1-6) (1994) 315-336. 